\title{
TREATMENT OF THE
}

GUILLAIN - BARRÉ SYNDROME 
'. 


\section{TREATMENT OF THE GUILLAIN - BARRÉ SYNDROME}

Behandeling van het syndroom van Guillain-Barré

\section{PROEFSCHRIFT}

Ter verkrijging van de graad van doctor aan de Erasmus Universiteit Rotterdam op gezag van de rector magnificus Prof. Dr. C.J. Rijnvos

en volgens besluit van het college van dekanen.

De openbare verdediging zal plaatsvinden op woensdag 9 mei 1990 om 15.45 uur

door

\section{RUDOLF PETER KLEYWEG}

geboren te Rotterdam 


\section{PROMOTIECOMMISSIE}

Promotor: $\quad$ Prof. Dr. A. Staal

Co-promotor: Dr. F.G.A. van der Meché

Overige leden: Prof. Dr. H.F.M. Busch

Prof. J.H.P. Wilson

Prof. Dr. H.J. Neyens

The Dutch Guillain-Barré trial is supported by:

Baxter Healthcare Corporation, Hyland Division and the American Red Cross. 
ter nagedachtenis aan mijn vader, aan Margreet, Suzanne en Erik 
Parts of this thesis were adapted from the following papers.

- Kleyweg RP, van der Meché FGA, Loonen MCB, de Jonge J, Knip B. The natural history of Guillain-Barré syndrome in 18 children and 50 adults. J Neurol Neurosurg Psychiatry 1989;52:853-856.

- Kleyweg RP, van der Meché FGA, Meulstee J. Treatment of Guillain-Barré syndrome with high-dose gammaglobulin. Neurology 1988;38:1639-1641.

- Kleyweg RP, van der Meché FGA, Schmitz PIM. Interobserver agreement in the assessment of muscle strength and functional abilities in Guillain-Barré syndrome. submitted for publication.

- Dutch Guillain-Barré study group.

Design of a multicentre trial comparing the effect of high-dose immunoglobulin with plasma exchange in Guillain-Barré syndrome. submitted for publication.

- Kleyweg RP, van der Meché FGA.

Treatment related fluctuations in patients with Guillain-Barré syndrome after treatment with immunoglobulins or plasma exchange. submitted for publication.

- Kleyweg RP, van der Meché FGA, Bänffer JRJ, Schmitz PIM, Meulstee $\mathrm{J}$, Rothbart $\mathrm{PhH}$, Oomes PG.

Campylobacter jejuni/coli infection and Guillain-Barré syndrome. in preparation. 


\section{CONTENTS}

List of abbreviations

General Introduction

Chapter 1. The Guillain-Barré syndrome: an introduction 3

1.1 The clinical syndrome 3

1.2 Preceding events 5

1.3 Immunological aspects 7

1.4 Neurophysiological studies 9

1.5 Treatment of Guillain-Barré syndrome 10

Chapter 2. The natural history of Guillain-Barré syndrome in eighteen children and fifty adults.

Chapter 3. Treatment of Guillain-Barré syndrome with high-dose immunoglobulins.

Chapter 4. Interobserver agreement in the assessment of muscle strength and functional abilities in Guillain-Barré syndrome.

Chapter 5. The Dutch Guillain-Barré trial comparing high-dose immunoglobulins with plasma exchange: design and course through the first interim analysis.

Chapter 6. Treatment related fluctuations in Guillain-Barré syndrome after high-dose immunoglobulins or plasma exchange.

Chapter 7. Campylobacter jejuni/coli infection and Guillain-Barré syndrome.

General summary and conclusions $\quad 59$

Samenvatting $\quad 63$

References $\quad 67$

Acknowledgements $\quad 78$

$\begin{array}{ll}\text { List of publications } & 79\end{array}$

Appendices $\quad 81$

$\begin{array}{ll}\text { Curriculum vitae } & 83\end{array}$ 


\section{LIST OF ABBREVIATIONS}

CIDP

CJC

CMAP

CMV

EAN

EBV

FFP

GBS

IgIv

PE
Chronic inflammatory demyelinating polyneuropathy

Campylobacter jejuni/coli

Compound muscle action potential

Cytomegalovirus

Experimental allergic neuritis

Epstein-Barr virus

Fresh Frozen Plasma

Guillain-Barré syndrome

Immunoglobulins, intravenously

Plasma exchange 


\section{GENERAL INTRODUCTION}

The Guillain-Barré syndrome (GBS) is an inflammatory polyneuropathy with an incidence of $1-1.8 / 100,000$. It is characterised by an acute or subacute onset and a progressive phase of less than four weeks, followed by a plateau phase of variable duration [106, 111]. Improvement then starts spontaneously; about $80 \%$ of the patients revover completely [135]. During the disease, $10-23 \%$ of the patients require artificial ventilation and there is still a mortality of $3-5 \%$. Ultimately, $10-22 \%$ of the patients remain disabled [106, 113, 135].

Since not all patients make an uneventful, complete recovery, the search for an effective treatment is going on continuously. The possible role of humoral components in the pathogenesis of GBS [30] prompted an open study with plasma exchange (PE) in a single patient with severe GBS. That was very successful [14]. After numerous case reports [28, 58, 109, 130, 141, $149,172]$ and several clinical trials $[50,57,61,131]$ examining the effects of PE in GBS patients, PE is now generally accepted as a treatment for patients with severe GBS [26].

PE carries, however, certain risks $[69,159]$. It is a cumbersome procedure and therefore not widely applicable. This prompted us to investigate an alternative treatment with immunoglobulins, given intravenously (IgIv), which forms the basis for this thesis.

Chapter 1 presents a general introduction of GBS paying particular attention to the clinical syndrome, antecedental events, immunological factors, neurophysiological studies and treatment.

We observed several children with very severe GBS. This is in contrast to the general opinion that children have a less severe form of the disease, and that they, therefore, do not require specific treatment such as PE [25, 106]. This led to a retrospective study comparing the natural history of GBS in children and adults. The study, described in chapter 2, showed that the degree of severity of GBS is similar in children and adults .

After succesfully treating patients with chronic inflammatory demyelinating polyneuropathy (CIDP) with IgIv $[179,185]$ we used IgIv to treat 8 patients with GBS. The results of this pilot study, which prompted us to set up a large clinical trial, are described in chapter 3.

One of the problems we encountered in the pilot study was that the generally applied functional scoring method, with broad categories, had limitations. This method, the "functional score" in our studies, seemed 
insensitive in certain categories. Therefore, we used an additional score, based on the guidelines of the Medical Research Council (MRC-scale) [118]. This score, the MRC-sumscore, is a summation of the strength of a number of muscle groups assessed according to the MRC-scale. Chapter 4 describes a study in which we analysed the sensitivity of both scores as well as the interobserver agreement.

In chapter 5 the design of a large multicentre trial comparing the effect of IgIv and PE in GBS patients is described. The background for this trial was that treatment with $\mathrm{PE}$ is a cumbersome procedure and that it is clear that IgIv is much easier to apply. Furthermore IgIv has fewer complications and can be applied in clinical situations where PE is not suitable, for instance in small children and patients with cardiovascular instability.

In the first two years of the trial 100 patients entered the study. In these 100 patients we noticed the occurrence of treatment related fluctuations after PE, as described by Osterman [132, 133] and Ropper [143] but also after IgIv. Others have emphasized that such fluctuations make the biological efficacy of the treatment more credible [132, 133, 143]. We studied 12 patients with treatment related fluctuations in more detail. This study is described in chapter 6.

Another aspect of GBS, studied in more detail in these first 100 patients, was the occurrence of preceding infections. In particular, Campylobacter jejuni/coli (CJC) infection and the possible relationship between such an infection and a more severe form of GBS was investigated. The results of this study are presented in chapter 7 . 


\section{CHAPTER 1}

\section{THE GUILLAIN - BARRÉ SYNDROME: AN INTRODUCTION}

\subsection{The clinical syndrome}

In 1916, Guillain, Barré and Strohl published their classical paper about 2 patients with "motor disturbance, abolition of tendon reflexes with preservation of cutaneous reflexes, paraesthesiae with slight affection of objective sensation, pain on pressing the muscles and a very marked increase in the albumin content of the cerebrospinal fluid without a cellular reaction" (the "dissociation albumino-cytologique" [59]). In 1927 the eponym "Guillain-Barré syndrome" was applied to the description of both patients and used thereafter to indicate similar conditions [38]. At the same time as Guillain and Barré described their patients, others reported, independently, identical cases occurring among British soldiers. These were given different names such as "infective polyneuritis" [85], "acute ascending paralysis" [22], "acute infective polyneuritis" [13] and "acute febrile neuritis" [68]. Thus, for many years, many different names were used for the same syndrome. In general, French authors applied the term GBS strictly to benign cases who made a good recovery. A "dissociation albumino-cytologique" should have been present; however, as already stressed by Guillain, this is certainly not pathognomonic for the syndrome. When there was a poor outcome, usually caused by involvement of the respiratory muscles, the disease was often referred to as "Landry's paralysis" [105]. After the introduction of temporary assisted ventilation in patients with respiratory problems, the difference between patients with a good and a poor outcome changed. Subsequently, when Haymaker and Kernohan [65] observed that patients with Landry's paralysis and GBS had a common pathology, the term Landry-Guillain-Barré syndrome was introduced.

Since the pathogenesis of GBS is still unknown and no definite diagnostic test is available, the diagnosis can only be based on a combination of criteria. The most recent consensus has been formulated by an ad hoc committee of the National Institute of Neurological and Communication Disorders and Stroke in 1978 (see appendix 1) [6].

With regard to these criteria, however, the following comment can be 
made. Relatively frequently, patients retain their myotatic reflexes until such severe weakness develops that they are no longer able to move their extremities against resistance (MRC score 3 or less). Such patients often have no sensory signs but in all other respects "typical" GBS. In my opinion, therefore, sensory fibres may be more important for the presence of myotatic reflexes than the degree to which motor fibres are involved. This also explains why in patients with complete recovery of motor function, tendon reflexes may still be absent if there is involvement of the sensory fibres. Pain is another phenomenon occuring in GBS [3, 23, 54, 142], which may delay a correct diagnosis. Patients sometimes present with such severe pain in the back or extremities that spinal cord compression or a dissecting aneurysm may be considered (personal observations). The cause of such severe pain is not known. In the case of an acute polyneuropathy with severe pain, it would seem prudent to consider the diagnosis Lyme disease. This disease, caused by the spirochete Borrelia burgdorferi may give rise to a syndrome that closely resembles GBS and should be treated with appropriate antibiotics [63, 166].

\section{Course of the disease}

Within 2 weeks of onset, more than $50 \%$ of the patients reach their maximum deficit; $90 \%$ has reached it within 4 weeks $[106,111]$. At their nadir, $10-23 \%$ of the patients require artificial ventilation [106, 113, 135]. A plateau phase follows, lasting one day to several weeks, before recovery starts; in general, recovery is much slower than the initial deterioration. After 4-6 months, about $80 \%$ of the patients have recovered satisfactorily [135], and $10-22 \%$ of the patients have residual deficits; $3-5 \%$ die during the acute phase [106, 113, 135]. Autonomic neuropathy often occurs and is expressed in many ways. Cardiovascular disturbances are the most serious autonomic signs and account for half of the mortality in GBS [84]. All forms of cardiac arrhythmia may arise, as well as hypertension and hypotension. Furthermore, urinary sphincter disturbances are present in about $40 \%$ of the patients [110].

Complete recovery is generally defined as normal or near normal muscle strength. In many cases, however, mild sensory disturbance, weakness or muscle pain after slight exertion occurs and precludes normal function despite apparently normal strength on examination. Therefore, a discrepancy may often exist between the clinical conclusion "complete recovery" and the patient's remaining complaints.

In an extensive study on patients with severe GBS, who were artificially ventilated, de Jager reported that only one third of patients recovered 
completely; one third recovered with only minimal deficits and one third was left with more moderate to severe weakness [34].

\subsection{Preceding events}

In 1892, Osler [129] was the first to describe the occurrence of an acute febrile illness preceding facial diplegia and limb weakness. Guillain and Barré, in 1936, distinguished two separate forms of GBS; one with a fatal and one with a good outcome. They suggested that they were caused by two different viruses [60].

It is now generally known that, upper respiratory and gastrointestinal infections in particular, often precede GBS. Approximately two-thirds of the patients give a history of an acute antecedent infection $[113,120,154]$. There is often an interval of one to three weeks between infection and neuropathic symptoms. Almost any organism has incidentally been described in relation to GBS but only a few controlled studies have been carried out. In particular, the Herpes viruses cytomegalovirus (CMV) and Epstein-Barr virus (EBV), Mycoplasma pneumoniae and recently CJC have been linked to GBS. In a controlled study, Dowling and Cook [37] demonstrated IgM antibodies against CMV in $15 \%$ of 220 GBS patients, but not in 40 healthy controls. They also found EBV infections preceding GBS in $8 \%$. Goldschmidt [56] detected antibodies to Mycoplasma pneumoniae in 5 of $100 \mathrm{GBS}$ sera and in only 2 out of 142 controls. In a controlled prospective study of 100 GBS patients, Winer [191] found a relationship between CMV and GBS in $11 \%$, but no relationship between EBV or Mycoplasma pneumoniae and GBS.

In the last ten years, many reports have appeared about the relationship between CJC infection and GBS $[144,122,92,33,27,139,162,138,163$, $164,165,192]$. This infection is now considered to be the most frequently occurring infection preceding GBS. There may also be a relationship between a preceding CJC infection and a poor course of GBS. A review of the literature and a prospective study of the relationship between CJC and GBS is given in chapter 7 .

\section{The swine flu incident}

The largest time cluster of GBS occurred in the USA following the A/New Jersey influenza ("swine flu") vaccination programme in 1976-'77 [156]. 45 million individuals were vaccinated. From the reported cases of GBS that followed shortly after the vaccination, it was estimated that vaccinated 
individuals had an increased risk ratio of 8.8 for developing GBS. For several years it was accepted that the increased incidence of GBS was related to the "swine flu" vaccination allthough this could not be explained. Later, a careful evaluation of the reports revealed several points of criticism [97]. The reports could only be studied after the federal court ordered the Centres for Disease Control to publish their data. Many data about the presumed GBS patients were provided by paramedical assistants and health officers. No diagnostic criteria for GBS were used. Records were abstracted by health workers with varying qualifications and no copies of clinical records were made for review. Follow-up was not systematic. A review of the abstracts revealed that $13 \%$ of "GBS patients" had unilateral involvement, $22 \%$ had no evidence of lower motor neurone involvement and after two years, $80 \%$ of the patients were listed as not having recovered, which is remarkable since $80 \%$ of true GBS patients recover within two years $[135,89]$. It remains, therefore, uncertain that there really was an outbreak of GBS due to the "Swine flu vaccination" in 1976-'77.

Another cluster of GBS patients was reported in Jordan in 1978 [161]. An area with 30,000 inhabitants was exposed to polluted water. After three weeks 5000 people were reported to be suffering from diarrhoea. During the third week after the diarrhoea outbreak, 16 patients with typical GBS were seen, of whom 13 had suffered from diarrhoea 8-23 days previously. In many investigations, stool culture was negative and no evidence of a recent viral or Mycoplasma infection was found. It is not clear whether or not the investigator specifically looked for CJC infection.

Recently, another outbreak of GBS occurred in Finland [87]. Shortly after a nation wide oral poliovirus vaccination campaign, a raised incidence of GBS was observed. In the first 3 months after the vaccination, the number of cases per 3 months increased significantly from 3 to 10 . No specific antecedent infection could be found despite extensive laboratory investigation. Because of the spontaneous fluctuating incidence of GBS, and the small number of unexpected cases after this polio vaccination, the authors were cautious about drawing definite conclusions.

A relationship has been described between GBS and zimeldine, a new antidepressive drug [43]. Within 18 months of its introduction, 13 cases of GBS occurred all within 2-5 weeks of zimeldine therapy being instigated. This represents a 25 -fold increase in risk of developing GBS. Since then zimeldine has been withdrawn from the market. 
Establishing relationships between e.g. CMV or CJC and GBS, has not resulted in clarification of the pathogenesis. The difficulty in detecting the mechanism might be that, in fact, a variety of different mechanisms is active in individual patients, all leading to the same clinical picture. Several possibilities for CMV are proposed here; chapter 7 will deal with the subject more extensively for CJC.

A direct pathogenetic effect, in which a virus invades the nerve and subsequently causes demyelination seems unlikely, as CMV has never been found in nerves of GBS patients, which otherwise show all the pathological hallmarks of GBS. CMV was only isolated from ventral roots in some patients with acquired immune deficiency syndrome and severe motor polyradiculopathy $[10,41]$. Other mechanisms might include the occurrence of the same, or almost the same, antigenic derterminants in myelin and virus. In this way, antibodies generated against a viral antigen may cross react with a similar antigen in peripheral nerve myelin. This mechanism is supported by the demonstration of viral antigenic determinants of measles, EBV, influenza A and B, that show homologies to central and peripheral nerve myelin [79]. In these circumstances, cross reactivity might occur, but is not yet proven in GBS.

\subsection{Immunological aspects}

In 1955, Wacksman and Adams [187] produced experimental allergic neuritis (EAN) in rats, mice and guinea pigs by immunizing them with peripheral nerve in complete Freunds adjuvant. Two weeks after the immunization, ataxia and limb weakness developed. One week later many animals started to recover. Morphological studies have shown that the first pathological change in the peripheral nerves is an infiltration of lymphocytes and monocytes that are transformed into macrophages [99]. These macrophages invade the nerve and strip myelin lamellae away from the Schwann cells. Subsequently, myelin disintegrates. This sequence of events closely resembles the pathology of GBS and suggests that EAN is a predominantly cell-mediated disorder.

The antigen responsible for the development of EAN in these animals is P2 $[80,146]$, a constituent of predominantly peripheral nerve myelin in both animals and man $[16,81]$. EAN, induced in rats, is considered to be a cellmediated immunological disorder [2, 7, 71, 99].

In rabbits, EAN can be induced after immunization with galactocerebroside [151]. Galactocerebroside is an important constituent of myelin. The histological lesions are confined to the peripheral nerves and consist of multifocal demyelination which is often not accompanied by the cellular 
infiltration so characteristic for EAN in rats. In this type of neuritis, Schwann cell damage is much more pronounced than in EAN induced in rats [62]. Galactocerebroside neuritis is considered to be primarily an antibody mediated disorder [151].

At present, it is not clear whether GBS in man is predominantly a cell- or a humoral-mediated disorder. Antibodies against P2 or galactocerebroside have not been found in serum from GBS patients [78, 93, 194]. The pathology of EAN in rats is very similar to that of GBS and therefore GBS has for a long time been considered to be a cell-mediated immune disorder. This has, however, not yet been confirmed.

There may be other arguments, supporting an important role of humoral factors. Intraneural injection of GBS sera into the sciatic nerve of the rat, may produce both morphological and physiological changes compatible with demyelination $[18,46,64,152]$. These effects, however, might be caused by aspecific immune mediators rather than specific disease related factors [128].

Specific antibodies to peripheral nerve myelin are present in a widely varying proportion of patients; the proportion depends on the test and the laboratory $[74,94,102,119,127,134,150,174,181,183,184]$. The antigen may be a glycolipid in the myelin but it has not yet been completely identified [94, 95, 75]. Results in antibody studies in our own patient group suggest that antibodies against the glycolipid Gm-1 may occur in about a quarter of the patients [Oomes in preparation]. The presence of antibodies against peripheral nerve myelin, however, does not necessarily mean that they also play a pathogenetic role [32].

The humoral hypothesis prompted attempts to treat GBS patients with PE with the intention of removing antibodies and also aspecific immune mediators present in plasma. As discussed below, several large clinical trials have shown that $\mathrm{PE}$ is followed by significant improvement, thus further supporting the role of humoral factors in man.

GBS is considered to be an autoimmune disorder. It is, however, surprising that GBS rarely occurs concurrently with other autoimmune disorders. In 1986, Behar [9] published a survey of the literature from 1966-1986; he described only 50 GBS patients who also suffered from a second (often chronic) autoimmune disorder, predominantly glomerulonephritis (16 patients). We recently saw one patient with GBS who, at the same time, developed idiopathic thrombocytopenic purpura [90]. This combination has never been described before, which is remarkable when one considers the similarities between these disorders: both are acute, usually self-limiting, frequently occur after an infection and moreover both seem to respond to IgIv. 


\subsection{Neurophysiological studies}

The pathological hallmark of GBS is segmental demyelination and cellular infiltration which, in severe cases, may be followed by axonal damage [5]. Demyelination starts in the paranodal region and the subsequently occurring dispersion of sodium channels results in conduction block [171]. Segmental demyelination is the ultimate result, which is followed by remyelination during recovery.

In clinical neurophysiology, conduction block is demonstrated by a decrease of the compound muscle action potential (CMAP). Such a potential is evoked by electrical stimulation of the nerve and recorded over the appropriate muscle with surface electrodes. The location of lesions can be determined by stimulating the nerve at several levels.

Different patterns of conduction block may be present in GBS patients $[177,178]$. In one group of patients, conduction block was present predominantly in the distal segments of the peripheral nerve: the CMAP was already low with distal stimulation of the nerve, whereas follow-up showed that this was not caused by axonal degeneration. In this group, sensory signs and symptoms were present. In the other group, conduction block was present over the entire length of the nerve. This was concluded from the observation that the CMAP decreased progressively with more proximal stimulation. This is a reflection of an increase of blocked nerve fibre segments with more proximal stimulation. Sensory signs were often absent in this subgroup.

For a long time, despite the well known pathology, a slowed nerve conduction velocity has been linked to GBS [6, 98, 115, 116, 117, 189]. Slowed nerve conduction velocity, however, is most likely caused by remyelinated fibres. Therefore, it is unlikely to be present in the acute phase but predominantly during recovery [17, 169].

The importance of a low CMAP after distal stimulation has been stressed as a poor prognostic factor in 3 recent studies [31, 121, 190]. A low CMAP may be the result of axonal degeneration in which case a very slow recovery can be predicted. Low CMAP's, however, may also result from extensive distal conduction block which need not be associated with a poor prognosis $[177,178]$. Differentiation in the first week of the disease is not feasible since other signs of axonal damage (fibrillation potentials and positive sharp waves) only develop later with a maximum around 4 weeks $[1,17$, 115].

Neurophysiological follow-up studies are therefore necessary to estimate prognosis in the individual patient. 
Despite the general idea that intense inflammation of the nerve is the cause of axonal damage, Feasby [47] has suggested that an axonal form of GBS may also exist. He described 5 patients with severe GBS who, early in the disease, had non-excitable nerves. At autopsy, one of these patients showed severe axonal degeneration without demyelination. In 3 of the 4 survivors recovery was poor.

In our own study of 42 consecutive GBS patients, eight had severe axonal degeneration [180]. During the first neurophysiological examination, within one week of onset, the majority of patients showed severe conduction block, the physiological hallmark of demyelination. Therefore, in the majority of patients it is assumed that severe axonal damage was preceded by demyelination. It cannot be excluded, however, that an additional axonal factor might have been present in these "demyelinative" patients.

\subsection{Treatment of Guillain-Barré syndrome}

\section{Introduction}

GBS is an acute, self-limiting disorder. With optimal supportive care, about $80 \%$ of the patients recover [135]. However, during the course of the disease 10 to $23 \%$ require artificial ventilation. Mortality amounts to $3-5 \%$ and approximately $10-23 \%$ have, sometimes quite serious, residual signs and symptoms $[106,113,135]$. These figures warrant the continued search for an effective therapy.

In the days of Landry (1859) and Guillain and Barré (1916) "chops and claret", chloroform and opium inhalations, electrical stimulation and vigorous antiseptic treatments with sodium salicilate, quinine and colloidal silver were all tried, and their efficacy sometimes "proven" [72].

Before discussing more recent therapy it is important to stress that whatever new treatment is applied, intensive supportive care is essential for an optimal recovery.

\section{Corticosteroids}

In 1951, when Haymaker and Kernohan [65] had just published a report stating that oedema of nerve roots was the initial event in the development of pathology, GBS was considered to be an allergic reaction and corticosteroids were tried the first time [160]. Since then, many reports have been published with with conflicting results and with a constantly changing opinion about the effect of steroids on GBS, varying from a sceptic 
approach in the beginning, enthousiasm in the 1960's and again a very sceptic attitude in the 1970's. At least two trials have been preformed with corticosteroids. In one [170], 16 patients were randomized to either ACTH or placebo. No immediate improvement occurred in the ACTH-treated group, but most patients received ACTH after reaching maximal disability. No firm conclusions can be drawn from this study because of the small sample size. In the second trial [70], forty patients were randomized to either prednisolone or placebo. Again the sample size was small. No beneficial effect of prednisolone was observed; on the contrary, patients with prednisolone probably did less well. Currently, however, interest in corticosteroid therapy is reviving and a clinical trial, studying the effect of high dose methylprednisolone, has been started in England.

\section{Plasma exchange}

The first attempt to perform PE in a GBS patient was reported by Brettle in 1978 [14]. He described a dramatic improvement in strength and functional abilities. Other publications soon followed indicating frequently an, impressive improvement after PE $[28,58,109,130,141,149,172]$ but not in all cases.

In 1984, six years after Brettle's first report, two small controlled randomised trials were published comparing $\mathrm{PE}$ with no $\mathrm{PE}[57,131]$. Both trials had certain methodological drawbacks. The suggestion from both studies was that PE may be beneficial in GBS patients, especially if performed early on in the disease. This was followed by two randomized trials, one in North America [61] and one in France [50], including 245 and 220 patients, respectively. In these studies, half the patients underwent PE while the others received supportive care only. Several important conclusions were drawn from these two studies. In the first place, recovery started earlier in the treatment group; 4 weeks after randomisation, $52 \%$ of the exchange group had improved 1 functional grade compared to $38 \%$ of the other group (95\% confidence limits of the difference $8-32 \%$, [61]). Secondly, the median time before patients could walk independently was reduced in the PE group with 32 days in one study [61] and 41 days in the other study [50]. Thirdly, in the North American study [61], the mean time of artificial ventilation, if instituted after randomisation, was only 9 days in the exchange group and 23 days in the conventional group $(\mathrm{p}<0.05)$. In the French study the time up to the beginning of weaning was 18 days in the exchange group but 31 days in the conservative group ( $p<0.005,[50])$. Finally, it has been confirmed that the effect of PE is most pronounced in patients treated early on in the course of their disease. 
As a result of these studies, a general consensus has been reached: in patients with severe GBS, PE is indicated [26]. Since PE is a complicated treatment, especially in GBS patients with autonomic nerve involvement and cardiovascular instability, PE will have to be performed in specialised centres [26].

Since the introduction of routine application of PE in GBS, it has become clear that in about $10 \%$ of the patients, after an initial response, a secondary deterioration occurs. This responds again to a second course of PE [132, 133, 143]. The explanation may be that the disease process in these patients is only temporarily suppressed and possibly lasts somewhat longer than generally presumed. These patients do not, however, develop chronic inflammatory demyelinating polyneuropathy (CIDP). Such treatment related fluctuations are considered to be additional evidence of the biological efficacy of PE $[132,133,143]$.

PE does, however, have certain drawbacks. As stated above, it is only available in specialized centres, thereby withholding treatment from patients who are not referred to such a centre. It is usually a cumbersome procedure for the patient. Furthermore, there are contraindications, especially cardiovascular instability such as recent myocardial infarction, unstable angina pectoris and severe autonomic disturbances associated with GBS, severe electrolyte disturbances and sepsis. Complications that may occur are citrate toxicity, hypotension, fluid overload, catheter infections, cardiac arrhythmia, thromboembolism, hepatitis if plasma is replaced, and bleeding diathesis and infection when albumin is used as replacement fluid $[140,159]$. At least 41 deaths, mainly due to cardiac arrhythmia, have been attributed to PE treatment [69]. These complications caused a $10 \%$ drop-out rate in the largest trial [61]. For all these reasons, a considerable number of GBS patients might not receive treatment with PE.

IgIv might be an attractive alternative. IgIv has presently been employed, with success, in an increasing number of immune mediated disorders including idiopathic thrombocytopenic purpura (ITP) $[48,76,125,126,158$, 186], Kawasaki's disease [51, 124], immune neutropenia [20, 66, 137], haemophilia due to anti-Factor VIII antibodies [21, 55, 168, 193], systemic lupus erythematosus [52], CIDP [42, 179, 185] and myasthenia gravis [36, $45,53,77]$.

The biological effects of IgIv have not been fully elucidated. Idiotypic anti-idiotypic interactions may play a role in Factor VIII deficiency and in CIDP [107, 168]. In ITP, T-suppressor cell activation [35, 175] and inhibition of macrophage activity by blockade of Fc receptors [125] occur. Furthermore, coating of red blood cells by IgIv, which are subsequently preferentially sequestrated by macrophages in stead of platelets, may play 
a role [153]. In experimental circumstances other mechanisms have been described [29]. Presumably, IgIv has a variety of immune modulating actions. Until the disease mechanism has been elucidated, the relative importance of these different mechanisms remains unclear in GBS.

Until now, IgIv has proven to be safe, especially with regard to transmission of HIV and hepatitis [126, 157]. There are few contraindications: the most important one - albeit rare - being an allergic reaction to blood products. Furthermore, if the IgIv preparation contains significant amounts of IgA, selective IgA deficiency is a contraindication. The study of the effect of IgIv in GBS will be discussed in chapters 3, 5 and 6. 


\section{THE NATURAL HISTORY OF GUILLAIN-BARRÉ SYNDROME IN EIGHTEEN CHILDREN AND FIFTY ADULTS}

\section{Introduction}

The Guillain-Barré syndrome (GBS) is a monophasic polyneuropathy from which many patients ultimately recover satisfactorily. However, artificial respiration is necessary in $10-23 \%$ of the patients in the acute phase of the disease, $10-22 \%$ finally remain disabled and there is a mortality of $3-5 \%$ $[106,113,135]$. For these reasons, an effective treatment has been sought and at present plasma exchange (PE), early in the course of GBS, is generally accepted as such [26].

In all trials leading to the acceptance of PE, children were excluded $[50,61$, 131]. Although the effect of PE in children is not really known, there is no reason to assume that it would not be effective. Case studies have shown that treatment related improvement does occur in children [88, 147].

The practical problems of $\mathrm{PE}$, however, especially in small children, makes us reluctant to apply this treatment. Moreover, it has been suggested that the outcome of GBS in children might be more favourable [25], making such a specific treatment unnecessary.

In order to decide whether PE should also be used in children, it is necessary to have more knowledge about the natural history of GBS in children compared with adults. Systematic studies on this subject are, however, not available.

Several reports on the severity of GBS in children are difficult to interpret because of variable methodology between and within the studies $[15,25$, $40,145]$. They suggest, however, that the acute phase might be more severe and clinical outcome worse than generally thought, but patient selection prevents conclusions about children in general.

To evaluate the need for specific treatment in children we therefore studied retrospectively the clinical course of all children and adults admitted to our clinic from 1975 until the introduction of PE in 1985. 


\section{Patients and methods}

Eighty four patients with GBS according to the generally accepted criteria [6] and admitted between 1975 and the time we started treating these patients with PE or immunoglobulin (IgIv) [88] -for adults 1985, for children 1987- were screened for inclusion in the study. Patients with predominant involvement of the cranial nerves ( 2 children and 4 adults) or the sensory system (1 adult) were excluded as well as patients with severe concurrent medical disorders interfering with functional abilities ( 3 adults: 1 with severe asthma, 1 with disabling rheumatoid arthritis and 1 patient with multiple myeloma). Six patients ( 1 child, 5 adults) lived too far away for follow-up in our hospital and were therefore excluded. From 4 adults we know, however, that they recovered between 6 months and 3 years after onset of the disease. The only child in this group had already considerably recovered at the time of discharge. We could not obtain any further information about one adult who could at least walk some distance unaided at the time he left hospital. Ultimately, 68 patients were studied; 18 children and 50 adults. None of these patients was treated with PE or IgIv. The clinical characteristics that were used to delineate the clinical course were: duration of the disease until maximum disability, duration of artificial ventilation, duration of hospitalization, and functional outcome one and two years after onset of the disease.

The functional status was assessed according to the grading system used in the North American trial [61], which we modified slightly (Table 2.1).

\section{TABLE 2.1}

\section{FUNCTIONAL GRADING SYSTEM}

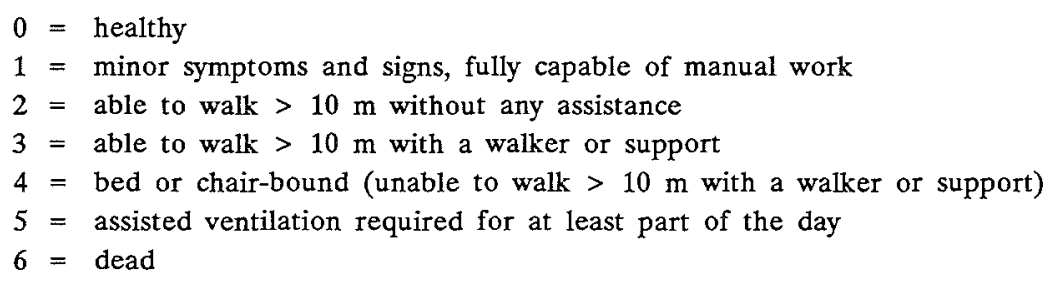

A clear distinction between grades 0 and 1 could not be made in retrospect, and so these grades have been combined, implying good recovery. In the final analysis, the patients were divided in two groups: patients who 
had made a good recovery (0/1) and patients who had a residual handicap or had died (grades 2-6). The great majority of the information was available in the medical records, sometimes the general practitioner was consulted in order to complete the follow-up data.

Statistical methods: The mean time until nadir, duration of artificial ventilation and duration of hospitalization were evaluated using the Mann Whitney $U$ - test. The percentage of patients that needed artificial ventilation in both groups was compared using the Fisher exact test.

\section{Results}

The 18 children studied were between 1 and 14 years old (median 7) whereas in the 50 adults, the age range was 16 to 74 years (median 32).

Severity of the disease (Table 2.2)

TABLE 2.2

SEVERITY OF THE DISEASE

\section{Children Adults \\ $(\mathrm{n}=18) \quad(\mathrm{n}=50)$}

Mean time \pm 2 se until nadir in days

$$
9.6 \pm 3.2 \quad 11.0 \pm 1.6(\mathrm{a})
$$

Artificial ventilation; percentage of patients, between brackets $95 \%$ confidence limits $22 \%(7-45 \%)$ $30 \%(18-45 \%)(b)$

Duration of artificial ventilation (days) mean: 21.5 32 (a) range:

$16-48$ $1-126$

Duration of hospitalization (incl. rehabilitation centre) (days) mean: range:

a: not significant: Mann Whitney U-test
b: not significant: Fisher exact test 
Time until nadir was similar in both groups.

Four (22\%) children required artificial ventilation versus $15(30 \%)$ in the adult group (not significant - Fisher exact test).

Median duration of artificial ventilation was 21.5 days in children and 32 days in adults (not significant - Mann Whitney $U$ Test).

Duration of hospitalization (including rehabilitation centre) was equal in the two groups, 84 and 86 days respectively.

\section{Final outcome}

The functional outcome was assessed after 1 and 2 years (Table 2.3) using the functional grading scale (Table 2.1). As mentioned before, functional grades 0 and 1 have been combined, indicating good recovery. In both groups the majority of patients had already recovered completely or nearly completely after 1 year; there was a slight increase in number of recovered patients after 2 years in both groups. Two children died from cardiac arrest, 1 in the acute phase, 1 in the plateau phase. In both death had been preceded by severe fluctuations in heartrate and blood pressure. One other child, a ten year old boy, had not made a good recovery within two years; he was in functional group 2. In the adult group, 4 patients were found to have made an incomplete recovery after 2 years; 1 was confined to a wheelchair ( 38 years) and 3 were in functional group 2 (23, 39 and 46 years respectively). When patients in grade 2-6 are considered together, $3(17 \%)$ children had not recovered completely after 2 years (this included two deaths), versus $4(8 \%)$ adult patients (Table 2.4).

\section{TABLE 2.3}

OUTCOME

\begin{tabular}{|c|c|c|c|c|}
\hline \multirow{2}{*}{$\begin{array}{l}\text { Functional } \\
\text { grade }\end{array}$} & \multicolumn{2}{|c|}{ One Year } & \multicolumn{2}{|c|}{ Two Years } \\
\hline & Children & Adults & Children & Adults \\
\hline $0 / 1$ & $14 \quad(77 \%)$ & $43 \quad(86 \%)$ & $15(83 \%)$ & $46 \quad(92 \%)$ \\
\hline 2 & $1(6 \%)$ & $4 \quad(8 \%)$ & $1(6 \%)$ & $3(6 \%)$ \\
\hline 3 & $1 \quad(6 \%)$ & $1 \quad(2 \%)$ & - & - \\
\hline 4 & - & $(4 \%)$ & - & $(2 \%)$ \\
\hline 5 & - & - & - & - \\
\hline 6 & $2(11 \%)$ & - & $2(11 \%)$ & - \\
\hline
\end{tabular}


TABLE 2.4

OUTCOME (CONTINUED)

\begin{tabular}{|c|c|c|c|c|}
\hline \multirow{2}{*}{$\begin{array}{l}\text { Functional } \\
\text { grade }\end{array}$} & \multicolumn{2}{|c|}{ One Year } & \multicolumn{2}{|c|}{ Two Years } \\
\hline & Children & Adults & Children & Adults \\
\hline $0 / 1$ & $14(77 \%)$ & $43(86 \%)$ & $15(83 \%)$ & $46(92 \%)$ \\
\hline $2 / 6$ & $4(23 \%)$ & $7(14 \%)$ & $3(17 \%)$ & $4 \quad(8 \%)$ \\
\hline
\end{tabular}

\section{Discussion}

Using artificial ventilation, length of hospitalization and functional outcome after one and two years as parameters for the severity of the disease, we have not been able to demonstrate statistically significant differences between eighteen children and fifty adults. The $95 \%$ confidence limits are, however, rather large reflecting the relatively small number of patients. Therefore no definite conclusions regarding the similarity of the two groups can be drawn. Recently it has been demonstrated that the prognosis is worse for adults over 40 years of age [190] compared to younger adults. It might thus be reasonable to consider children and adults under 40 years of age as a single group having a better prognosis than the older patients. It has recently been shown that the duration of the disease before the plateau phase is reached is of prognostic importance [114]. Again this parameter did not differ between the two groups.

The percentage of patients who needed artificial ventilation is somewhat larger than generally mentioned in the literature, presumably because our hospital is also a secondary referral centre for more severely affected patients. In both groups the percentage of patients who finally made a complete recovery is in agreement with the literature [106].

For a description of the severity of GBS, we choose to focus not only on the final outcome but also on the duration of artificial ventilation, and the duration of hospitalization. These latter parameters concerning disease severity are frequently not mentioned when discussing the need for treatment, and only the final outcome is taken into account [25]. The duration of hospitalization and artificial ventilation with its complications are, however, also important factors influencing the decision whether or not to apply PE, especially since these latter factors can be influenced by PE [61]. From our data, we conclude that specific treatment should be considered not only in adults but also in children with GBS. Although the ultimate outcome is often excellent, it would certainly not seem superfluous to 
attempt to influence the clinical course: the mean duration of hospitalization of all children has been 84 days and the mean duration of artificial ventilation in four children 21.5 days.

Although PE has proved its beneficial effects in clinical trials performed exclusively in adults, there is no reason to believe that it would be less effective in children. Case reports, including our own observation [88, 147] suggest beneficial effects. PE, however, is a cumbersome procedure with practical difficulties especially in smaller children. It should, therefore, be reserved for more severely affected children, in whom the beneficial effects of PE will outweigh the technical difficulties.

In the near future, IgIv might be an alternative, even for the smallest children. Recently, we described the promising experience with this treatment in eight GBS patients, including one eleven-year-old child [88]. Application of this treatment must, however, await the results of the ongoing Dutch multicentre trial - in which children are also included - to compare the effect of PE with IgIv.

Preliminary results have been presented on the first conference of the European Neurological Society in Nice in June 1988. 


\title{
TREATMENT OF GUILLAIN-BARRÉ SYNDROME WITH HIGH-DOSE IMMUNOGLOBULINS
}

\section{Introduction}

\begin{abstract}
Although many patients with Guillain-Barré syndrome (GBS) make a satisfactory recovery, a search has been made for an effective treatment since there still is a mortality of about $5 \%, 10-23 \%$ of the patients require artificial ventilation and $10-22 \%$ remain disabled [106, 113, 135]. Plasma exchange (PE) has been shown to be effective in GBS in several clinical trials. The treated patients were ambulant one month earlier and time spent on the respirator was significantly reduced [50,61]. It is therefore generally accepted that PE is indicated in severely affected patients with GBS. However, PE has restrictions; there are complications, contraindications and this treatment should only be performed in selected hospitals, thereby withholding treatment from many patients. High-dose intravenous immunoglobulins (IgIv) might be a practical alternative. Moreover there are hardly any contraindications. It is easily applicable in all hospitals and has proved to be safe [157].

The therapeutic effect of IgIv in patients with chronic inflammatory demyelinating polyneuropathy (CIDP) [185] prompted this open study in Guillain-Barré patients.
\end{abstract}

\section{Patients and methods}

We included eight patients who fulfilled the criteria for the diagnosis of GBS [6]. Two severely affected patients were initially treated with PE and subsequently with fresh frozen plasma (FFP) or IgIv. Subsequently, six consecutive patients, admitted between October 1985 and March 1986, received only IgIv. None were able to walk independently and all were still deteriorating, so they fullfilled the generally accepted criteria for treatment with PE [26]. In all patients, the diagnosis was supported by neurophysiological studies that showed a decreased nerve conduction velocity or conduction block. Treatment started within two weeks after onset (Table 3.1). 


\section{TABLE 3.1}

PATIENT CHARACTERISTICS

\begin{tabular}{lcccll}
\hline $\begin{array}{l}\text { patient } \\
\text { number }\end{array}$ & sex & age & $\begin{array}{l}\text { duration } \\
\text { illness } \\
\text { in days }\end{array}$ & $\begin{array}{l}\text { respiratory } \\
\text { support } \\
\text { necessary }\end{array}$ & $\begin{array}{l}\text { CMAP-APB } \\
\text { before } \\
\text { treatment } \\
(\mathrm{mV})\end{array}$ \\
\hline 1 & F & 11 & 6 & yes & 2.7 \\
2 & F & 27 & 4 & yes & 0.1 \\
3 & M & 46 & 6 & no & 6.2 \\
4 & M & 64 & 5 & yes & 4.4 \\
5 & F & 49 & 13 & no & 0.8 \\
6 & M & 35 & 10 & no & 2.7 \\
7 & M & 66 & 3 & no & 0.2 \\
8 & F & 59 & 6 & no & 3.2 \\
\hline
\end{tabular}

* CMAP-APB: compound muscle action potential measured over the abductor pollicis brevis after median nerve stimulation at the wrist; measurements within two weeks of onset.

IgIv was given at a dose of $0.4 \mathrm{~g} / \mathrm{kg} /$ day for 5 consecutive days (we used IgIv prepared by Central Laboratory Dutch Red Cross and IgIv prepared by Travenol).

Patients were scored every other day during the first three weeks and subsequently once a week until discharge. Functional assessment was performed according to the grading scale used in the North American trial (Table 2.1, [61]). Early alterations in strength could not, however, be detected sufficiently by this method; therefore, we developed a more sensitive score. Six muscle groups (Table 3.2) were tested on both sides using the MRC-score (Table 3.3). Summation of the scores yielded a MRCsumscore, ranging from $0-60$.

\section{TABLE 3.2}

MUSCLE GROUPS (RIGHT AND LEFT) ASSESSED IN THE MEASUREMENT OF THE MRC - SUMSCORE

\footnotetext{
Abduction of the arm

Flexion of the forearm

Extension of the wrist

Flexion of the leg

Extension of the knee

Dorsal flexion of the foot
} 
MRC - SCALE WITH FULL FIGURES ONLY. THE PATIENT IS INVESTIGATED IN SITTING POSTURE AND/OR LYING SUPINE [118].

$0=$ no visible contraction

1 = visible contraction without movement of the limb (not existent for hip flexion)

2 = movement of the limb but not against gravity

3 = movement against gravity over (almost) the full range

4 = movement against gravity and resistance

5 = normal

\section{Results}

\section{Patients treated with plasmapheresis and FFP/IgIv}

Patient one: an eleven-year-old girl, developed weakness at the end of June 1983. She became tetraparalytic twelve days after onset and artificial ventilation was required on July $4 . \mathrm{PE}$ was initiated at this stage. In four sessions, performed within a period of eight days, $8 \mathrm{l}$ was exchanged. She improved rapidly and could be extubated 15 days later. At that time, strength was grade 4 (MRC) in the arms and 1-2 in the legs. One week later, however, she deteriorated, again becoming tetraparalytic. During a new series of PE's, she improved again so that she could walk independently. This was followed by a third deterioration; she became confined to bed again. Another course of PE was considered to be too demanding; instead, she received FFP, 11 /day for four consecutive days. This induced improvement within three days, similar in all respects to the recovery after PE. Full recovery followed. The total duration of the disease had been four months. No recurrence occurred during a follow-up period of four years. Clinical improvement was reflected in all neurophysiological measurements (Table 3.4).

Patient two: a twenty-seven-year old woman, was admitted to another hospital four days after the onset of weakness. On admission she was tetraparalytic and artificial ventilation had to be instituted the same day. On the next day, the first of a series of five exchanges was performed. Three days after the first PE she started to improve, and three weeks later she could breathe independently and move her arms against gravity. She was in this condition when transferred to our clinic, 4 weeks after admission. After transfer, she again deteriorated; she became tetraparalytic and needed artificial ventilation. She received IgIv and on the second 
treatment day there was a marked improvement. The arms, which had again been paralysed, could now easily be raised against gravity. More distal muscles also improved. This was reflected in the neurophysiological studies (Table 3.4). After this rapid improvement, further recovery was much slower but almost complete.

\section{TABLE 3.4}

PHYSIOLOGICAL STUDIES OF THE MEDIAN NERVE BEFORE AND AFTER TREATMENT

\begin{tabular}{|c|c|c|c|c|c|}
\hline & $\begin{array}{l}\text { grasp- } \\
\text { force } \\
(75)^{*} \\
(\mathrm{kPa})\end{array}$ & $\begin{array}{l}\text { DML } \\
(3.7) \\
(\mathrm{msec})\end{array}$ & $\begin{array}{l}\text { NCV } \\
(60) \\
(\mathrm{m} / \mathrm{sec})\end{array}$ & $\begin{array}{l}\text { CMAP } \\
\text { wrist } \\
(10) \\
(\mathrm{mV})\end{array}$ & $\begin{array}{l}\text { CMAP } \\
\text { elbow } \\
(10) \\
(\mathrm{mV})\end{array}$ \\
\hline $\begin{aligned} \text { patient } 1: & \text { before FFP } \\
& \text { after FFP** }\end{aligned}$ & $\begin{array}{l}29 \\
36\end{array}$ & $\begin{array}{r}10.5 \\
8.2\end{array}$ & $\begin{array}{l}22 \\
29\end{array}$ & $\begin{array}{l}2.7 \\
4.8\end{array}$ & $\begin{array}{l}3.0 \\
4.1\end{array}$ \\
\hline & $\begin{array}{l}\text { APB } \\
(\mathrm{MRC})\end{array}$ & DML & $\mathrm{NCV}$ & $\begin{array}{l}\text { CMAP } \\
\text { wrist }\end{array}$ & $\begin{array}{l}\text { CMAP } \\
\text { elbow }\end{array}$ \\
\hline $\begin{aligned} \text { patient 2: } & \text { before IgIv } \\
& \text { after } \operatorname{IgIv}{ }^{* *}\end{aligned}$ & $\begin{array}{l}1 \\
3\end{array}$ & $\begin{array}{l}26.2 \\
21\end{array}$ & $\begin{array}{l}32 \\
50\end{array}$ & $\begin{array}{l}0.1 \\
0.7\end{array}$ & $\begin{array}{l}0.1 \\
0.6\end{array}$ \\
\hline
\end{tabular}

* between brackets limit of normal.

** interval between the two studies: 9 days.

FFP $=$ Fresh frozen plasma

IgIv = Intravenous immunoglobulin

$\mathrm{DML}=$ Distal motor latency

NCV = Nerve conduction velocity,

CMAP = Compound muscle action potential of the abductor pollicis brevis muscle (APB).

Patients treated only with IgIV

In four of the six consecutively treated patients, IgIv seems to have been effective. Their clinical course is illustrated in the Figure 3.1. In two patients ( 3 and 4 ), the effect was most marked; progressive deterioration was reversed to improvement within 24 hours after onset of treatment. None of the four patients had the plateau phase, so characteristic of 
severely affected GBS patients. Patient 6 showed deterioration after initial improvement followed by another favourable response after a second treatment (Figure 3.1). Thereafter he made a rapid and complete recovery. Two patients showed no effect following IgIv. Neurophysiological studies, however (Table 3.1), showed abundant denervation potentials in combination with a low compound muscle action potential (CMAP); their recovery was slow and incomplete, all in contrast to the other patients.

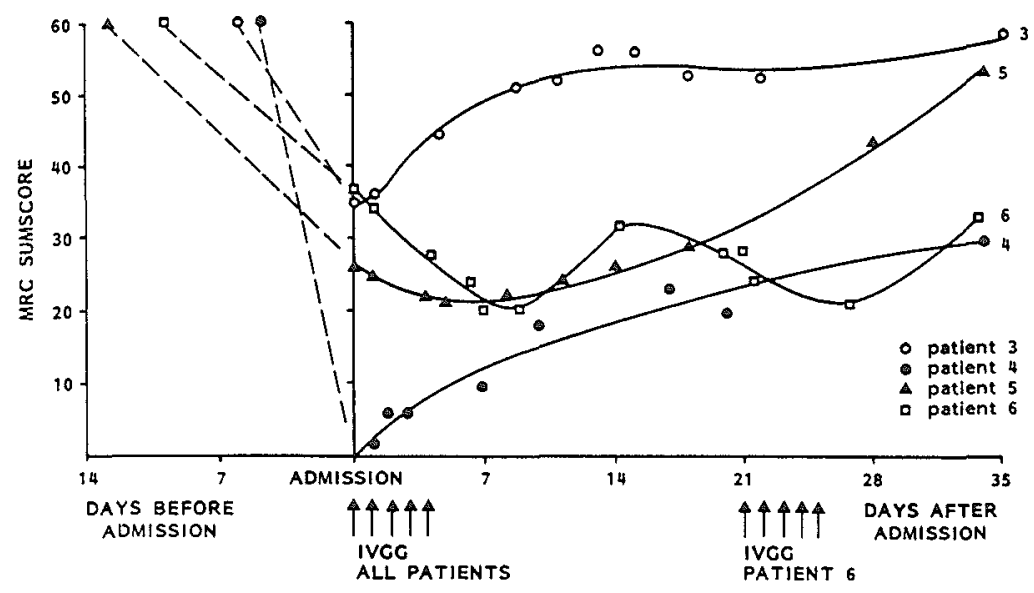

Figure 3.1 Clinical course as reflected by the course of the MRC-sumscore in four patients responding to high-dose intravenous gammaglobulin (MRC-sumscore of 60 represents normal strength, 0 represents tetraparalysis).

The dashed lines indicate the duration and course of the disease before admission.

\section{Discussion}

These clinical observations suggest IgIv has a beneficial effect on the clinical course of GBS. The arguments are the following:

1. Two patients ( 1 and 2 ) who showed initial improvement after PE, deteriorated again and subsequently showed a similar improvement after FFP or IgIv.

2. Four of six consecutive patients, who could not walk unaided and who were still deteriorating, improved after IgIv without a plateau phase (Figure 3.1). Patient 4, who became tetraparalytic within five days, 
improved after the first infusion (a very unlikely event during the natural course of the disease). In this group one patient deteriorated after initial improvement; repeated treatment was again followed by improvement (patient 6).

Only two patients did not improve after IgIv. Neurophysiological studies showed that, in contrast to the other patients, both had severe axonal degeneration. This explains also their slow and incomplete recovery.

Secondary deterioration in GBS patients after an initial successfull response to treatment (as we observed in three patients) is a recently described phenomenon; all such patients seem to respond again to a second treatment course [132].

This treatment modulated time course in GBS patients should, however, not be confused with CIDP. In this syndrome disease activity persists usually over years with only temporary improvement after either PE [39] or IgIv [185]. None of our patients had late relapses.

The mode of action of IgIv in inflammatory polyneuropathy is not known. In other diseases a positive clinical effect has been ascribed to both aspecific mechanisms, such as competitive inhibition of macrophages [153] and specific mechanisms such as anti-idiotypic suppression of autoantibodies [168].

Specific mechanisms might also be present in GBS, especially since antimyelin antibodies have recently been described in all GBS patients [94]. Treatment with IgIv might have several therapeutic advantages over PE. It is easily infused without any delay and is widely available. Moreover costs are comparable.

IgIv is considered to be safe with regard to viral transmission including HIV [157] and has widely been used without serious complications.

We conclude that the response to IgIv in severely affected Guillain-Barré patients might be comparable to the PE effect. Before clinical application, these results should be confirmed in a large trial. Recently we started a randomized multicentre trial, involving at least 200 GBS patients, comparing Iglv with PE. 


\title{
CHAPTER 4
}

\author{
INTEROBSERVER AGREEMENT IN THE \\ ASSESSMENT OF MUSCLE STRENGTH AND \\ FUNCTIONAL ABILITIES IN \\ GUILLAIN-BARRÉ SYNDROME
}

\section{Introduction}

In several studies about the effect of plasma exchange (PE) in GuillainBarré syndrome (GBS) functional deficit is assessed using a categorized scale [50,61]. The scale, used in the North American trial [61] was originally developed by Hughes [70] and later slightly modified by others $[61,88]$. It has the advantage that each change in category is of definite clinical importance. Moreover, most steps between the categories are well defined. Therefore, one might expect a high interobserver agreement, which is especially important in multi-centre studies. However, this scale is rather insensitive to early clinical changes. This has recently been demonstrated in GBS patients in whom secondary clinical deterioration, after an initially successful response to $\mathrm{PE}$, was not always indicated by a change in functional score [143]. In the ideal situation, a grading system should be easily applicable and relevant to the clinical condition; there should be a high intra- and interobserver agreement and the sensitivity should be sufficiently high to detect relevant changes.

In the Dutch Guillain-Barré trial, comparing high dose immunoglobulins (IgIv) with PE, we introduced a second score, which had been tested in a pilot study [88]. This score is a summation of the strength of six muscle groups tested on both sides (Table 3.2) according to the MRC-scale (Table 3.3), yielding a so called MRC-sumscore. These muscle groups can easily be tested against gravity. Both proximal and distal muscle groups are represented in the MRC-sumscore. In the present study we determined the sensitivity and interobserver agreement of both scoring systems. Furthermore, we studied the relationship between the MRC-sumscore and the grasp force, measured on a continuous scale, by dynamometry. 
All GBS patients who were studied in the Dutch Guillain-Barre trial were examined according to a predefined schedule for a period of six months. Initially, examination took place three times a week, the frequency gradually decreasing to once a month at the end of the follow-up period. Functional score and MRC-sumscore were assessed at each examination. The functional score was assessed using a grading system described in Table 2.1.

For the interobserver analysis, two groups of GBS patients were studied. The first group, the "trial group", consisted of 60 patients of the Dutch Guillain-Barré trial, consecutively tested by one of us (RK). In this multicentre trial IgIv (Gammagard ${ }^{R}$, Baxter) was compared with PE in patients with GBS who became unable to walk independently within two weeks of onset. In order to control whether there was any bias in this non-blinded trial, one of the coordinators visited every patient in the cooperating centres. At that time he was unaware of the treatment modality. The functional score and the MRC-sumscore were assessed by coordinator and treating neurologist on the same day, independently of each other. After documentation, the results were discussed as part of a continuous programme to optimize the scoring methods.

The second group, the "resident group", consisted of 15 consecutive patients, all admitted to the Academic Hospital of Rotterdam between November 1987 and January 1989.

Ten senior residents of the neurology department were paired to form 30 different couples. Each couple examined one patient twice with an interval of several weeks. Before each examination, the patient was seen by one of us (RK) who assessed the functional and MRC-sumscore and explained the procedure to the patient. The patient was examined by both members of the couple on the same day but they were unaware of each others findings. During each examination the functional score and MRC-sumscore were assessed and written on a standardized data form. Only once, at the beginning of the study, we explained thoroughly, how the patients should be scored; all residents were familiar with testing muscle strength according to the MRC-scale. In total, 60 paired observations were made of the patients at different stages of their disease.

In order to examine the relationship between the MRC-sumscore and the grasp force, eleven GBS patients admitted to the Academic Hospital of Rotterdam were followed longitudinally by one of us (RK) for several months, measuring MRC-sumscore and grasp force at the same time. 


\section{Statistical methods}

Calculation of interobserver agreement was performed for the "trial group" as well as for the "resident group". For the functional score kappa statistics were used [24]. For the MRC-sumscore we decided that a difference in MRC-sumscore of less than $10 \%$, of the total range (0-60), i.e. a score of less than 6 between two observers, would be acceptable and therefore judged as agreement. A difference of more than $10 \%$ implies no agreement. Furthermore, intraclass correlation coefficients were calculated [100].

For comparison of the MRC-sumscore and grasp force measured by handdynamometry we calculated Fisher's correlation coefficient.

\section{Results}

\section{Sensitivity of the functional score and $M R C$-sumscore}

The sensitivity of the functional score and MRC-sumscore was studied by simultaneously measuring these scores at different stages of the disease. In Figure 4.1 the clinical course for a single typical patient, as reflected in MRC-sumscore and functional score, is shown. When the patient is still deteriorating, the MRC-sumscore declines while the functional score remains the same. Also recovery is first noticed in the MRC-sumscore and only later in the functional score. After the first 100 patients in the Dutch GBS trial, about $30 \%$ have shown such a difference in sensitivity between the course of the functional score and the MRC-sumscore.

We also analysed the range of MRC-sumscores of all patients in a certain functional group. Figure 4.2 shows the relationship between the functional score and the MRC-sumscore of 60 patients in the "trial group" measured by both observers. Within functional groups 1,2 and 3 there is limited variation in the MRC-sumscore, whereas in functional group 4 and 5 the MRC-sumscore ranges from 0 to 55 . The same pattern is seen in the observations in the "resident group".

This relationship does not change if the functional score is related to the MRC-sumscore of the arms or legs separately. 


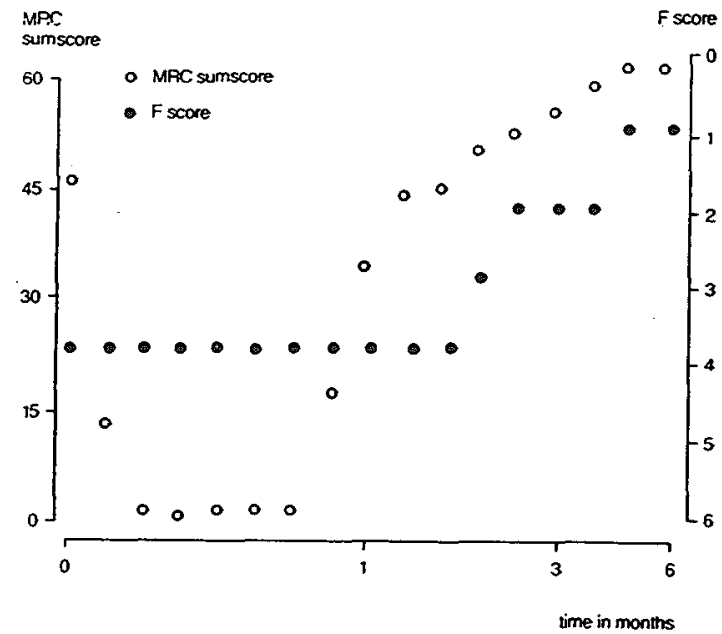

Figure 4.1 Clinical course as depicted by MRC-sumscore and functional $(F)$ score

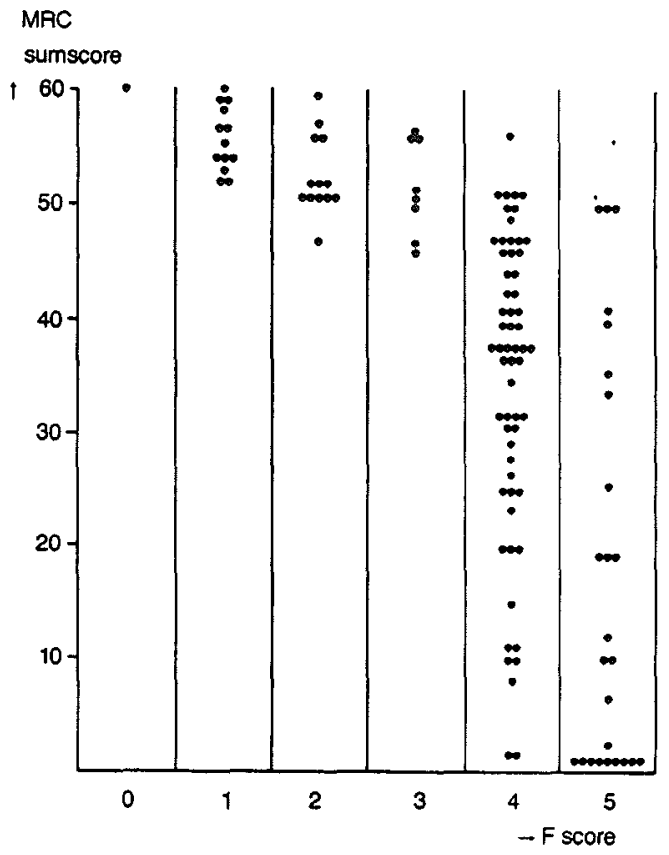

Figure 4.2 Relationship between functional $(F)$ score and MRC-sumscore in 60 patients, measured by two observers at the same arbitrarily chosen time in the course of the disease 
In the "trial group", there was agreement on the functional score in 53 out of 60 paired scores $(88.3 \%$ ) (Figure $4.3 \mathrm{a}$ ); correction for chance results in a kappa value of 0.85 .

Figure 4.3b shows the results of the study in the "resident group", here the observed agreement is $86.7 \%$ and after correction for chance, the kappa value is 0.80 . The maximum difference in functional score was one point, occuring predominantly between functional scores one and two.

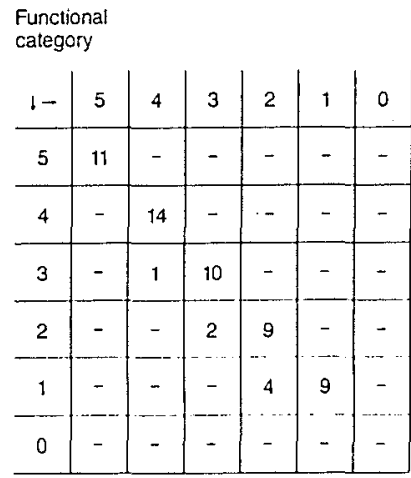

$K a p p a=0.85$

Functional
category
\begin{tabular}{c|c|c|c|c|c|c|}
\hline $1-$ & 5 & 4 & 3 & 2 & 1 & 0 \\
\hline 5 & 12 & - & - & - & - & - \\
\hline 4 & 1 & 29 & - & - & - & - \\
\hline 3 & - & 1 & 4 & - & - & - \\
\hline 2 & - & - & 1 & 3 & - & - \\
\hline 1 & - & - & - & 4 & 4 & - \\
\hline 0 & - & - & - & - & 1 & - \\
\hline
\end{tabular}

$\mathrm{Kappa}=0.80$

(b)

Figure 4.3 Observed agreement in functional score between observers in the "trial group" (a) and between observers in the "resident group": (b)

Interobserver agreement on the MRC-sumscore

Figure 4.4a shows the correlation between the MRC-sumscores measured in the "trial group". The agreement is expressed in an intraclass correlation coefficient which is $0.98\left(\mathrm{r}^{2}=0.96\right)$. The relationship between the MRCsumscores measured in the patients examined by different pairs of residents is reflected in Figure 4.4b; intraclass correlation coefficient is $0.96\left(\mathbf{r}^{2}=0.93\right)$.

If we assume that a difference of less than $10 \%$ (less than 6 points on the scale 0-60) between two MRC-sumscores means agreement, then there is agreement between two observers in the "trial group" on $90 \%$ of the observations, and on $78 \%$ between the residents. In this latter group there was one observer who scored systematically lower than the others. If one disregards this observer's results then there is good agreement on $89 \%$ of the observations. 

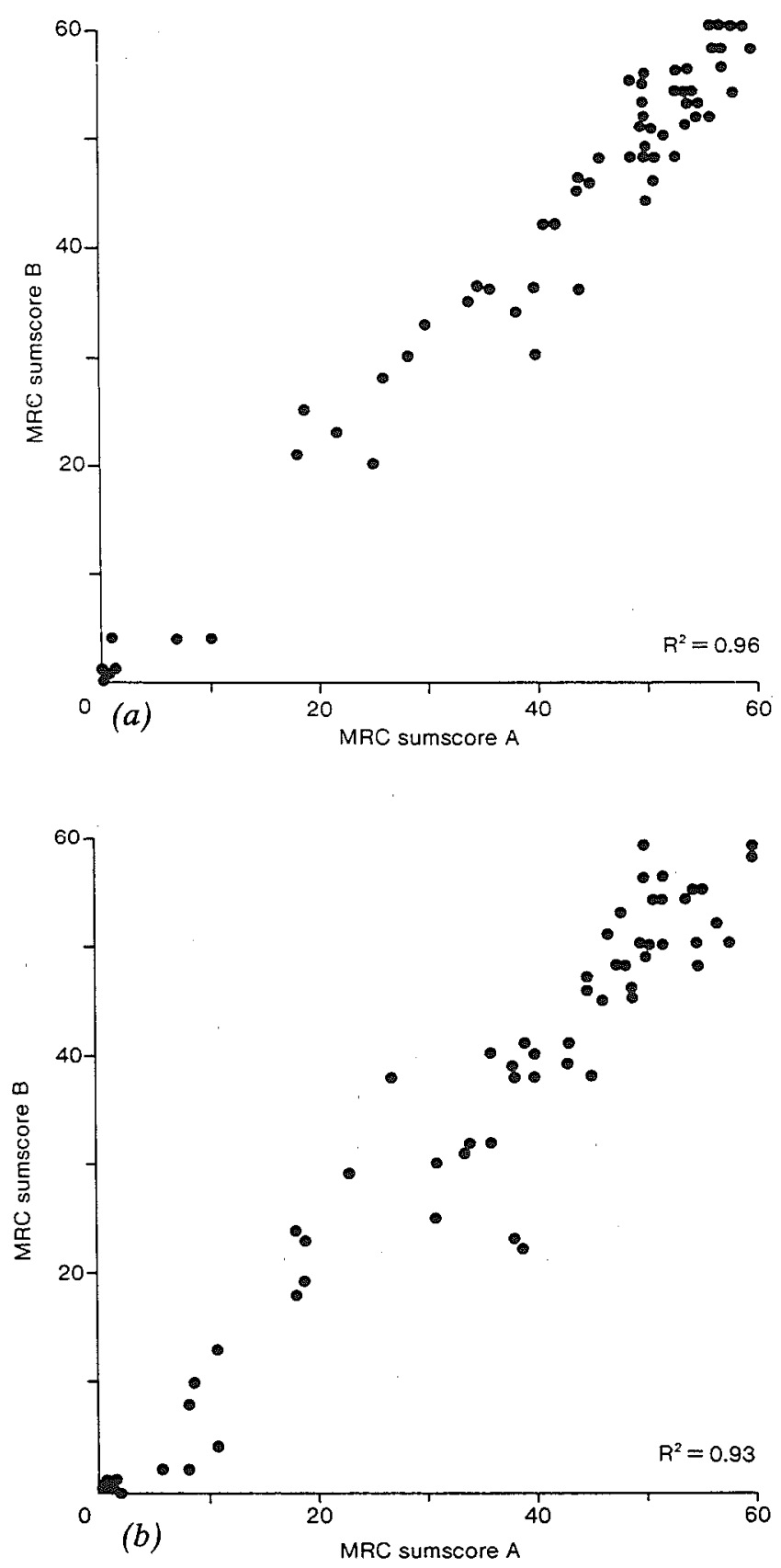

Figure 4.4 Relationship between MRC-sumscore measured by two observers in the "trial group" (a) and measured by two observers in the "resident group" (b) 
Eleven patients were followed over a period of several months with regular measurements of the grasp force and MRC-sumscore during the same examination. The course of the MRC-sumscore and grasp force in the individual patient ran often parallel and the correlation coefficients between grasp force and MRC-sumscore for these patients ranged from 0.80 to 0.99 with a median of 0.91 .

\section{Discussion}

A considerable change in the clinical condition can occur as reflected by the MRC-sumscore without any accompanying change in functional score. Allthough chair-bound or bedridden on admission, a patient can still be quite strong. Subsequently he or she may become tetraparalytic and then improve again without any change in functional score (Figure 4.1). In general, it appears that functional grades 4 and 5 are compatible with a wide range of MRC-sumscores (Figure 4.2). In contrast, in functional scores 1-3, the MRC-sumscores are in a narrower range. One may therefore conclude that, especially for patients who are bedridden or receiving artificial ventilation (grade 4 and 5), measurement of the MRC-sumscore contributes valuable information about the clinical course. In the higher functional categories (1-3), the MRC-sumscore adds little extra information.

There are several possible explanations for the wide range of MRC-sumscores in functional grades 4 and 5 . The functional score is mainly an indication of the neurological condition of the legs. Hence, a considerable change in MRC-sumscore without a change in functional score might be explained by changing strength of the arm muscles, without a change in muscle strength of the legs. This contention has, however, not been supported by analysis of the MRC-sumscores of arms and legs separately. Other possible explanations for being bed- or chair-bound (score 4) despite considerable strength are the presence of severe sensory defecits or predominantly proximal weakness. Furthermore, in the ventilated group, respiratory muscles may be more selectively involved and also complications of artificial ventilation may extend the time spent on the respirator, despite improved muscle strength.

To be useful in further studies, interobserver agreement on these scoring methods must be high. Interobserver agreement can be expressed in a kappa value which corrects the level of observed agreement for chance agreement; kappa values of 0.80 and higher indicate perfect agreement 
according the guidelines of Landis and Koch [101]. For the functional score, there was almost perfect agreement in the two groups; the value for the trial group being slightly better. The distinction between functional catagories 1 and 2 is sometimes difficult as was also reported in a recent trial [61].

Measurement of the MRC-sumscore resulted in high intraclass correlation coefficients of 0.98 and 0.96 indicating excellent agreement. If one considers a difference of less than $10 \%$ in MRC- sumscore between two observers to be good agreement, then the "trial group" has $90 \%$ agreement versus $78 \%$ in the resident group. In the paired observations with a considerable difference in MRC-sumscore, the patients were often being artificially ventilated and some were receiving sedatives, leading to fluctuation of cooperation during the day.

The difference in agreement between the two groups might be explained by the fact that in the trial group one observer was always the same; moreover the centre investigator always received feedback in order to optimize scoring within the trial. In the other group, the residents were informed only at the beginning of the study and were usually not familiar with the patient. Moreover, in this group there was one observer who consistently scored considerably lower than the scoring partner. In this case, intraobserver agreement might be better than interobserver agreement.

One might argue that the MRC-score is a very crude means of assessing muscle strength. Each muscle group is scored on a very a-linear, ordinal scale; grade 4 in particular spans a large range of muscle strength. One cannot, therefore, deny that dynamometers or myometers would give a more exact assessment of strength. These methods are, however, much less practicable for daily bedside examination and require extensive standardization and training before usage. Furthermore this method is not suitable for very weak muscles (MRC grade 1-3). On the other hand, when we compare the MRC-sumscore with a hand dynamometer score then, in general, there is a strong correlation between these two scores during the acute, plateau and recovery phase.

The MRC-sumscore has proved to be a reliable way of obtaining an overall impression of muscle strength and one might, according to the central limit theorem [67], regard the MRC-sumscore as a continuous variable.

In conclusion: both the functional score and the MRC-sumscore have an almost perfect interobserver agreement; this might even be improved by regular feedback about the results. The MRC-sumscore is more sensitive to changes in clinical course than the functional score in the more severe functional grades. If one uses this MRC-sumscore in addition to the functional score, it is possible to follow the clinical course in more detail and recognize when recovery begins and a secondary relapse occurs. 


\section{THE DUTCH GUILLAIN - BARRÉ TRIAL COMPARING HIGH-DOSE IMMUNOGLOBULINS WITH PLASMA-EXCHANGE: DESIGN AND COURSE THROUGH THE FIRST INTERIM ANALYSIS}

\section{Introduction}

The Guillain-Barre syndrome (GBS) is a subacute inflammatory demyelinating polyneuropathy with an incidence of about 1.8 per 100.000 . On the basis of longitudinal neurophysiological studies, it has been suggested that, within the limits of the syndrome, different patterns of conduction failure may exist; one with lesions scattered along the nerves and one with lesions more restricted to the distal part of the nerves [177, 178]. The disease may lead to a severe tetraparesis and artificial ventilation is often required. Although functional recovery is the rule, $15 \%$ of patients show a residual deficit [3]. For these reasons, more specific therapy has been sought in addition to supportive care. Based on an increasing interest in specific and aspecific humoral factors that might be involved in the pathogenesis of GBS [173]), plasma-exchange (PE) has recently been evaluated in a number of clinical trials $[50,57,61,131]$.

It has been shown that with PE patients improved faster and the period of artificial ventilation is significantly shortened as compared with supportive care alone. These effects were especially present in patients for which treatment was started early in the course of the disease. Therefore, consensus has been achieved that PE is indicated in those patients who have a considerable deficit and are still early in their disease [26]. These criteria were defined in our study as an unability to walk independently and within 2 weeks of disease onset.

Over the same period that the PE-trials were conducted we performed open, non-randomized studies with high-dose intravenous immunoglobulins (IgIv). Initially, we performed an open study in chronic inflammatory demyelinating polyneuropathy (CIDP) $[179,185]$. Encouraged by the positive results in these patients, we performed a pilot study in GBS patients [88]. From this we concluded, that IgIv might have the same 
biological potential as PE in the treatment of GBS. Similar to the initial case reports describing the effect of $\mathrm{PE}$, we saw some patients dramatically improving soon after IgIv therapy. Other patients, however, showed little or no effect. This could perhaps be explained by the presence of severe axonal degeneration precluding any rapid improvement. However, since GBS patients characteristically show spontaneous recovery, no definite conclusions could be drawn without a formal randomized trial.

The rationale for IgIv therapy was based on the observation that IgIv has been shown to have a beneficial effect in idiopathic thrombocytopenic purpura [76] and other autoimmune mediated diseases, e.g. myasthenia gravis [4, 29] and autoimmune factor VIII deficiency [168]. The biological effects of IgIv are not fully understood, but it is clear that it may have a wide range of actions on the immune system. Under a variety of conditions, it has been shown that idiotypic - anti-idiotypic antibody interactions might occur $[107,168,181]$, that B-cells $[12,19,176]$ and $T$ helper cells $[12,29]$ are down regulated and that the activity of phagocytes is inhibited by blockade of Fc receptors [153]. The mechanisms that might play a role in GBS are not clear, since the exact pathogenesis of GBS is not known. Comparable to $\mathrm{PE}$, the effect has to be judged from clinical studies alone. If we assume that IgIv and PE might have the same biological potential, why start a multicentre study comparing their effects? The main argument is that IgIv is easily, quickly and everywhere applicable, whereas PE is a much more cumbersome procedure to perform (Table 5.1). Furthermore, many hospitals do not have PE facilities, which results in delay of treatment until the patient can be referred to a specialized centre, or in no treatment at all if such a centre is not available. In specialized centres it frequently takes a day to start PE. For example, in the North-American trial [61] 72 hours were allowed after randomization to begin the procedure. All such delays occur during the phase of often rapid progression of the disease.

\section{TABLE 5.1}

PRACTICAL ADVANTAGES OF IGIV OVER PE

1. everywhere available and applicable

2. hardly any contra-indications

3. no treatment delay

4. practically no drop outs

5. better tolerable and less dangerous for the patient 
Furthermore, there may be contraindications for PE, especially cardiovascular instability caused by preexistent disease, severe infection, or autonomic dysfunction due to GBS. Finally, treatment may have to be discontinued during its course because of side effects. In the North American trial, a $10 \%$ drop out rate was reported [61].

On the other hand, IgIv is easily given in any hospital at any time and has very few contraindications, the primary one being known allergic reactions to bloodproducts, which is rare. IgA deficiency is a contraindication, if the IgIv preparation contains significant amounts of IgA product. However, the product used in our study (Gammagard ${ }^{\mathrm{R}}$, Baxter) is not contraindicated in this situation. Moreover, safety with regard to viral transmission has been established in experimental and large clinical studies [103, 104, 157]. Therefore, based on these arguments, if the biological activity is similar, IgIv is the preferred therapy. Thus, it was appropriate to prove that, within certain predefined statistical limits, both treatments have the same beneficial effect. Such clinical trials are called conservative.

This report presents the background of the Dutch Guillain-Barré trial and states in advance the statistical procedures in the analysis of the main outcome criteria.

\section{Design of the study}

It is a conservative, randomized trial and analysis will be performed on an "intention to treat" basis.

\section{Study objective}

The primary question to be answered: is IgIv as effective as PE in improving the clinical course of GBS-patients?

The secondary question to be answered: is it possible to discriminate responders from non-responders early in the course of the disease on the basis of specific pathophysiological patterns [177, 178].

\section{Study population}

Patients were included in the study if they fulfilled the criteria for acute GBS (Table 5.2) [6], were not able to walk 10 meters independently and were admitted to the hospital within two weeks of onset of the neuropathy. 
Features required for diagnosis

- Progressive motor weakness of more than one limb

- Areflexia or marked hyporeflexia in very weak muscles (grade 3 MRC or less)

- CSF cell counts of no more than 50 monocytes or 2 polymorphonuclear leukocytes per $\mathrm{mm}^{3}$

Features strongly supportive of the diagnosis

- Progression over days to a few weeks

- Relative symmetry

- Mild sensory signs or symptoms

- Cranial nerve involvement

- Onset of recovery 2-4 weeks after halt of progression

- Autonomic dysfunction

- Initial absence of fever

- Elevated CSF protein after 1 week of symptoms

- Abnormal electrodiagnostics with slowed conduction or prolonged $F$ waves

Features required to rule out other diagnosis

- No history of hexacarbon abuse

- No evidence of porphyria

- No history or culture evidence of diphtheria

- No history or evidence of lead intoxication

- Symptoms not purely sensory

- No evidence of poliomyelitis, botulism, toxic neuropathy (ethanol), organophosphates or thick paralysis.

Patients were excluded from the study if they were below 4 years of age, had a previous episode of GBS, had a previous severe allergical reaction to blood products, had known selective IgA deficiency, were pregnant, were on immunosuppressive treatment, had a severe concurrent medical disease or were unable to be followed for six months.

Note that "known selective IgA deficiency" was used as an exclusion criteria since not all IgIv products are safe in this respect.

With these criteria we intended to include the full range of patients diagnosed in general neurological practices with GBS. The results of the trial, therefore, will be directly applicable to the usual clinical situations.

\section{Treatment}

$\mathrm{PE}$ is started as soon as possible after randomization but under optimal conditions following the guide lines of the consensus conference [26]. It is intended to exchange $200-250 \mathrm{ml}$ plasma per kg. body weight in 5 sessions 
within 7-14 days. Replacement fluids do not contain IgG, 5\% albumin is most often used. As soon as possible after randomization IgIv treatment is started. During 5 subsequent days $0.4 \mathrm{~g} / \mathrm{kg} /$ day of IgIv (Gammagard ${ }^{\mathrm{R}}$ Baxter) is given.

Recently, it has become apparent that in $10-20 \%$ of the patients the primary response to treatment may be followed by a secondary relapse that again responds to treatment $[132,133,143]$. Therefore, the possibility has been included in the protocol to repeat the same treatment if after partial recovery or stabilization of more than one week duration secondary deterioration follows. Such a decision is always taken after contact with one of the study co-ordinators.

Randomization is performed immediately after clinical diagnosis. For this reason we use a 24 hour telephone service supplied with randomization lists, stratified only by centres. After randomization, treatment has to start as soon as possible. The randomization procedure is controlled by a statistician.

\section{Measurement of motor function}

To enhance comparability of GBS-studies, motor function is expressed on a crude functional scale used in previous trials with only a slight modification (Table 2.1) $[57,61,88]$ - note that the walking distance in grades 3 and 4 has been increased from 5 to 10 meters to discriminate more effectively between a short walking distance and stumbling a few steps - . This scale has the advantage of expressing the factual functional abilities of the patients. Therefore, the calculation of the number of patients and the major outcome criterion has been based on this scale. On the other hand, because of the crudeness of the scale, fluctuations in the clinical course are not easily detected. Especially the treatment related fluctuations in 10 $20 \%$ of the patients are not always reflected in a change in functional score. For that reason we have introduced a second, more detailed score based on the addition of MRC-scores of 6 bilateral muscles groups giving a range from 60 (normal) to 0 (tetraparalytic) (Table 4.2).

Scoring systems in multicentre trials need to have adequate interobserver reliability. Therefore, a formal study of interobserver agreement of these two scoring methods is performed (Chapter 4).

\section{Control of bias}

Blinding of PE studies in GBS patients is not feasible. Control of bias, however, becomes significant if the outcome criterion is more subjective. 
Motor function as an outcome criterion of efficacy, however, is a rather objective parameter. On the other hand, investigators might favor one of the therapies, for practical or theoretical reasons. Being aware of this problem, we introduced a method to measure whether bias is occurring. Before randomization, the functional score and $\mathrm{MRC}$-sumscore are documented. Later every patient in the study is scored once by one of the study co-ordinators, still blinded for the therapy. The blind scores are compared with the scores of the centre investigator. As patient data accumulates, it is possible to observe bias in favour of either therapy. After the first 100 patients, this did not occur. In 82 of the comparisons there was agreement. Compared to the score of the study co-ordinators the centre investigators scored 5 times one grade worse in both the PE and IgIv groups and 5 times and 3 times better in the IgIv and PE groups, respectively.

\section{Main outcome criterion}

The main outcome criterion for the study is the proportion of patients with one or more grades improvement on the functional scale 4 weeks after randomization. This criterion has been chosen because it has obvious clinical relevance and because it has been used in previous trials, enabling us to use those data to make calculations about the number of patients required for our study.

\section{Number of patients}

A formula to estimate the number of patients necessary in a conservative trial has been devised by Makuch and Simon [108]. In general, such a calculation is not based on tests of significance, but on the $95 \%$ confidence limits for the difference in the outcome criterion between the two treatments groups. This formula is given below.

$N=p_{1} x\left\{\left(1-p_{1}\right)+p_{2} \times\left(1-p_{2}\right)\right\} \times\left[\frac{z_{\alpha}+z_{\beta}}{\delta-\left(p_{1}+p_{2}\right)}\right]^{2}$

$\mathrm{P}_{1}$. In the North American trial [61], 59\% of the patients treated with PE improved functionally within a month. This percentage was calculated by using only those patients who received full treatment and excluding the dropouts. The present trial uses a pragmatic or intention to treat paradigm, i.e. all randomized patients in both treatment arms are compared whether or not they actually completed the protocol. We used this approach since 
we want to know the effect in general clinical practice of using either PE or Iglv as a therapeutic strategy. For this reason the "explanatory" percentage of $59 \%$ has been decreased to $55 \%\left(\mathrm{P}_{1}\right)$.

$\mathrm{P}_{2}$. In the IgIv arm, less dropouts are to be expected. Furthermore, the start of IgIv treatment is not delayed to any extent after randomization. Thus, it can be assumed that, given an equal biological effect, the IgIv arm will show a better result. It has been estimated that $65 \%$ of the IgIv treated patients will show improvement on the functional scale within four weeks $\left(\mathrm{P}_{2}\right)$.

$\delta$. Delta specifies the upper bound for the one sided $95 \%$ confidence limit for $\mathrm{P}_{1}-\mathrm{P}_{2}$. For this study this has been set at $7 \%$. The value of $7 \%$ suggest that, if IgIv is no worse than $7 \%$ different from PE, then we would conclude that the treatments are at least clinically equivalent. The meaning of this specification is further demonstrated in the next example. If the trial shows that the difference between IgIv and PE is $10 \%$ in favor of IgIv, then $\mathrm{P}_{1}-\mathrm{P}_{2}=-10 \%$ with $95 \%$ confidence limits of $-25 \%$ up to +5 . Then, treatment with IgIv is with a confidence of $95 \%$, at highest $5 \%$ worse than treatment with $\mathrm{PE}$, but might be better also.

$\mathrm{Z}_{\alpha}, \mathrm{Z}_{\beta}$. The chance of an error of the first type has been set at 0.05 and the second type at $0.2 ; \mathrm{Z}_{\alpha}$ and $\mathrm{Z}_{\beta}$, the standard normal percentiles are then 1.6449 and 0.8416 , respectively.

The number of patients estimated by substituting these figures in the formula gives approximately 100 patients in each arm or 200 patients in total.

\section{Follow-up schedule}

The functional score and the MRC-sumscore are assessed 17 times during a follow-up period of 6 months. The frequency varies from three times a week shortly after randomization to once in 4 weeks in the last few months. Neurophysiological studies are performed at randomization and one and four weeks later. The median and ulnar nerves are primarily investigated and both the motor and sensory fibres. The amplitude of the compound muscle action potential (CMAP) with distal stimulation is obtained, since this has been proven to be a prognostic factor in other studies [31, 190]. Furthermore, the amount of conduction block as evidenced by progressive decrease of the CMAP with more proximal stimulation is measured. Recently, we were able to define different pathophysiological patterns with this criterion that might reflect different pathogenetic mechanisms [177, 178]. It is important to evaluate in GBS whether this might discriminate between responders and non-responders, although this seems not to be the case in CIDP [179]. 
Other studies include routine blood, urine and cerebrospinal fluids studies. More specifically, porphobilinogen and $\delta$-amino-levulinic acid in urine are assessed to exclude porphyria, and serological studies directed at infections, known to occur in relation to GBS, are performed.

\section{Statistical analysis}

Interim analyses will be performed after 100 and 150 patients. Besides the obvious aim of stopping the trial early if the study objective has been met, adverse effects in both groups can be controlled and other aspects like the effectivity of randomization with regard to prognostic factors might be evaluated.

A stopping rule for a conservative trial does not exist in the statistical literature. Therefore, initially a very conservative rule had been included in the protocol: the trial should end if after 100 patients one of the two treatments proved superior $(\mathrm{P} \leq 0.05$, with correction for two analysis $P \leq 0.03$ ). During the course of the study, before the interim analysis, it became clear that this was not appropriate for ethical reasons. If PE shows a better result, one should stop as soon as it becomes clear that the primary aim cannot be obtained. On the other hand, if IgIv shows a better result one should stop if the main aim has been reached and not only when it is statistically superior. Since the majority of data had been accumulated at that point, it was decided to perform the first analyses with the initial conservative stopping rule and to perform a second interim analysis after 150 patients with a new stopping rule based on the main aim of the study. It has been formulated as follows: the upper bound of the one sided $99 \%$ confidence limit for $P_{1}-P_{2}$ should be $7 \%$ or less. The $99 \%$ instead of the $95 \%$ confidence limit has been chosen to correct for multiple testing and to ensure that a convincing result has been obtained if the trial should stop at 150 patients.

\section{First interim analysis}

Between November 1986 and November 1988100 patients were randomized (Figure 5.1). One month after randomization of the 100th patient, an interim analysis has been performed. The results of this analysis will not be given in detail here to avoid premature conclusions before the study has ended. A number of general statements can be made, however. 


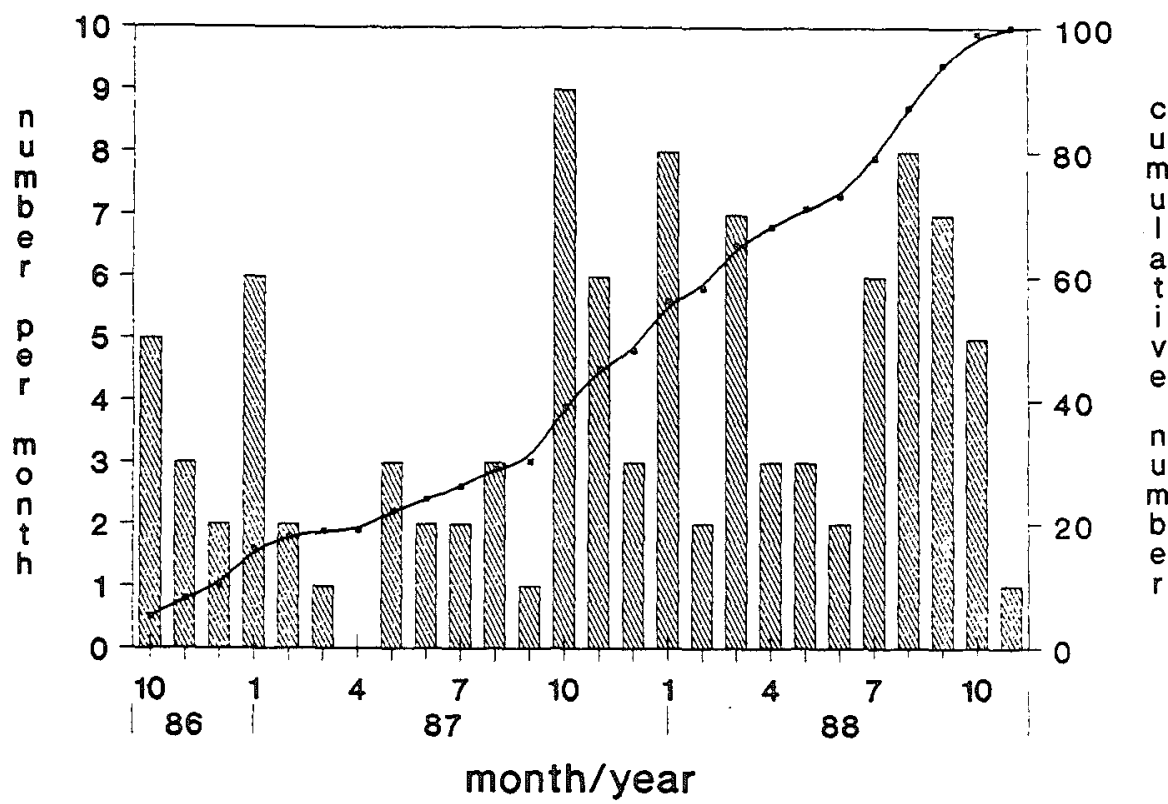

Figure 5.1 Accrual of the first 100 patients in the study. Bars: number of patients per month; drawn line: cumulative number.

1. Of the 100 patients randomized, two were withdrawn because they were not eligible. One patient had myelitis transversa instead of GBS and the second patient had severe concurrent disease, notably instable angina pectoris.

2. No patients were lost for follow-up.

3. The treatment results did not meet the criterion of the initial stopping rule. The study is therefore continuing.

4. Complications like pulmonary infections, thrombosis and cardiovascular disturbances needing treatment, occurred in an equal number of patients in both groups, but more patients in the PE-group had multiple complications. No serious adverse effects were noticed from IgIv therapy.

5. The prognostic factors age, amplitude of the distal CMAP and duration of the disease before randomization were not significantly different in the two groups.

6. No bias occurred as determined by the comparison of the blind score of the co-ordinator with the score of the centre investigator.

The next interim analysis is expected at the end of 1989. Two hundred patients are expected to be included before the end of 1990. A full list of the participating centres and committees is given in appendix 2 . 


\section{TREATMENT RELATED FLUCTUATIONS IN GUILLAIN-BARRÉ SYNDROME AFTER HIGH-DOSE IMMUNOGLOBULINS OR PLASMA EXCHANGE}

\section{Introduction}

In Guillain-Barré syndrome (GBS), relapses occur in about $3 \%$ of the patients, after a symptom free interval of weeks, months or years [3]. A relapse rate of $10 \%$ has been reported [135] but one should now consider that many of these relapsing patients were suffering from chronic inflammatory demyelinating polyneuropathy (CIDP). In a retrospective study of the natural history of GBS in 68 consecutive patients we observed no relapses [89].

Several trials have recently established the beneficial effect of plasma exchange (PE) [50, 61]. Since the wider application of this treatment, early relapses have been shown to occur in patients with initially a good response $[132,133,143]$. Osterman described 6 patients out of a series of 37 of whom 23 responded to PE. These 6 patients deteriorated again 2 - 4 weeks after completion of PE [133]. In Roppers series, 10 out of 94 patients with GBS relapsed 5-42 days after PE [143]. When a second series of PE 's was subsequently performed, they again observed a favourable response. Occasionally, a third treatment was necessary; during follow-up (8 months to 5 years), however, none of these patients developed CIDP. The fluctuating course of these patients is considered to be induced by the temporary effect of PE on the actual disease process, which, in these cases, is longer than a few weeks. To avoid confusion with the sometimes relapsing course of CIDP we think that it is preferable to use a more specific description, such as "treatment related fluctuations" rather than "relapses". The occurrence of such treatment related fluctuations after PE is considered to be an additional strong argument in favour of the biological effect of PE [132, 133, 143]. In a recent pilot study on the effect of high-dose immunoglobulins administered intravenously (IgIv), one GBS patient showed such treatment related fluctuatiuons after IgIv [88]. Since then, one hundred GBS patients have been treated in the Dutch Guillain- 
Barré trial comparing IgIv with PE. As part of an interim analysis, we analysed the treatment related fluctuations in both groups on the basis of the hypothesis that if IgIv has similar biological efficacy as PE, such fluctuations should occur with equal frequency in both groups.

The final comparison of the effect of the two treatments must await the ultimate results of the ongoing Dutch trial. These should be available in the near future. The present study does, however, confirm the biological efficacy of IgIv in GBS, which we suggested before [88]; therefore, it should now be considered to apply IgIv in patients who require treatment but who have contraindications for PE.

\section{Patients and methods}

The first hundred patients of the Dutch Guillain-Barré trial were all screened for relapses after an initial response related to PE or IgIv. PE was performed by cell separator or by membrane ultrafiltration; $200-250 \mathrm{ml}$ per $\mathrm{kg}$ body weight was exchanged in 10-14 days. Immunoglobulins (Gamma$\operatorname{gard}^{R}$, Baxter) were administered intravenously in a dose of $0.4 \mathrm{~g} / \mathrm{kg} /$ day for five consecutive days.

All patients were examined three times a week, then after two weeks with a gradually decreasing frequency up to 26 weeks. During each visit a functional score (F score, Table 2.1) was assessed, as well as the MRCsumscore, obtained by adding the MRC-scores of six muscle groups on each side (Table 3.2). The MRC-score is assessed according to the guidelines of the Medical Research Council (Table 3.3). The MRC-sumscore, ranging from 0 (total paralysis) to 60 (normal strength), gives an overall impression of muscle strength. All patients were still deteriorating at the time of admission and unable to walk independently. They were treated with either PE or IgIv as soon as possible, but always within 2 days of randomization.

A treatment related fluctuation has been defined as:

1. improvement in functional score of at least 1 grade or improvement in MRC-sumscore of more than 5 points within 4 weeks, followed by a decrease in the MRC-sumscore of more than 5 points or a worsening in functional score of at least 1 grade or:

2. stabilisation of the clinical course for more than one week followed by a further worsening with more than 5 points on the MRC-sumscore or at least 1 grade of the functional score. In the last situation, an arrest of progression for more than one week, is considered to be caused by treatment and not to be in accordance with the natural course. Improve- 
ment, stabilization and deterioration had to be documented in at least two subsequent examinations by the same investigator.

\section{Results (Table 6.1)}

From the first hundred patients of the Dutch Guillain-Barre trial, 12 patients - 5 of 49 in the PE group and 7 of 51 in the IgIv group - showed a secondary deterioration after an initial response to treatment. Of these 12 patients, 3 were not retreated; 6 received a second treatment course and 3 required several treatment courses.

In the group of 9 patients, who received no or only one extra treatment, 4 patients were in the PE group and 5 received IgIv. Duration of the neurological signs prior to treatment had been between 3 and 8 days. Six patients showed improvement after treatment, starting 2-13 days (median 4 days) after the onset of therapy and ranging between 6 and 34 points MRCsumscore. Three patients showed stabilization of the clinical course after initiation of treatment.

Relapses occurred 10 - 60 days (median 21 days) after treatment was started. The decline, however, was usually not as severe as before the initial response. In two patients, 2 and 6 , there was considerable delay between treatment and secondary deterioration. Follow-up, however, showed that these patients cannot be considered to have CIDP.

In 4 of the 6 patients the second treatment course was followed by improvement after 5 - 10 days (median 8.5 days) without any further deterioration. The course of a typical patient in this group (patient 4 ) is illustrated in Figure 6.1a. In two patients ( 2 and 5) deterioration, leading to a second treatment, was arrested. Subsequently they recovered more slowly.

Three patients, who did not receive a second treatment, improved again, shortly after their relapse. Patient 7 is typical for this group; his course is illustrated in Figure 6.1b.

After 6 months, 2 patients ( 1 and 8 ) were still chairbound, although they were recovering slowly; all others made an excellent recovery. No further relapses occurred during the follow-up period which spanned $12-40$ months. 
TABEL 6.1

PATIENTS WITH TREATMENT RELATED FLUCTUATIONS WHO RECEIVED EITHER ONE OR NO RETREATMENT

\begin{tabular}{|c|c|c|c|c|c|c|c|c|c|c|c|c|c|c|c|c|c|}
\hline \multirow[t]{2}{*}{ Patient } & \multirow[t]{2}{*}{ Age } & \multirow{2}{*}{$\begin{array}{l}\text { Treatment } \\
\text { IgIv/PE }\end{array}$} & \multirow{2}{*}{$\begin{array}{l}\text { Disease duration } \\
\text { before treatment }\end{array}$} & \multicolumn{2}{|c|}{ Admission } & \multicolumn{2}{|c|}{ Nadir } & \multicolumn{3}{|c|}{ Response $1^{*}$} & \multicolumn{3}{|c|}{ Relapse** } & \multicolumn{2}{|c|}{ Response $2 * * *$} & \multicolumn{2}{|c|}{ Six months after Admission } \\
\hline & & & & $\mathbf{F}$ & $\mathrm{MRC}$ & F & $\mathrm{MRC}$ & $t_{1}$ & F & $\mathrm{MRC}$ & $t_{2}$ & $\mathbf{F}$ & MRC & t3 & response & $\mathbf{F}$ & MRC \\
\hline 1 & 57 & $\mathrm{PE}$ & 8 & 4 & 28 & 4 & 26 & 7 & 4 & 34 & 24 & 4 & 26 & 10 & improvement & 4 & 37 \\
\hline 2 & 29 & $\mathrm{PE}$ & 3 & 4 & 46 & 4 & 38 & 13 & 2 & 56 & 60 & 4 & 41 & 0 & stabilisation & 2 & 53 \\
\hline 3 & 24 & IgIv & 3 & 3 & 48 & 3 & 48 & 0 & 3 & 48 & 21 & 5 & 45 & 10 & improvement & 1 & 56 \\
\hline 4 & 66 & Iglv & 6 & 3 & 48 & 4 & 48 & 4 & 4 & 54 & 21 & 4 & 48 & 7 & improvement & 1 & 58 \\
\hline 5 & 14 & IgIV & 4 & 4 & 43 & 4 & 43 & 0 & 4 & 43 & 10 & 4 & 30 & 0 & stabilisation & 1 & 58 \\
\hline 6 & 20 & $\mathrm{PE}$ & 5 & 4 & 46 & 5 & 26 & 4 & 2 & 58 & 40 & 2 & 48 & 5 & improvement & 1 & 60 \\
\hline 7 & 74 & IgIv & 3 & 4 & 30 & 5 & 0 & 4 & 5 & 34 & 21 & 4 & 22 & no & 2nd treatment & 0 & 60 \\
\hline 8 & 56 & IgIv & 3 & 5 & 32 & 5 & 32 & 0 & 5 & 32 & 21 & 5 & 24 & no & 2nd treatment & 4 & 42 \\
\hline 9 & 42 & PE & 3 & 3 & 46 & 3 & 46 & 2 & 2 & 58 & 11 & 3 & 53 & no & 2nd treatment & 0 & 60 \\
\hline
\end{tabular}

$\left({ }^{*}\right)$ response $1=$ best score after treatment; $t_{1}=$ time from start of treatment until the onset of the response in days.

$\left({ }^{*}\right)$ relapse $\quad=$ lowest score before secondary improvement or stabilisation; $t_{2}=$ time until onset of relapse in days after the start of the first treatment. $\left({ }^{* *}\right)$ response $2=$ improvement or stabilisation-within 2 weeks after the start of the second treatment; $t_{3}=$ time after the start of the second treatment in days.

$\mathrm{F} \quad=$ Functional score

MRC $=$ MRC-sumscore 


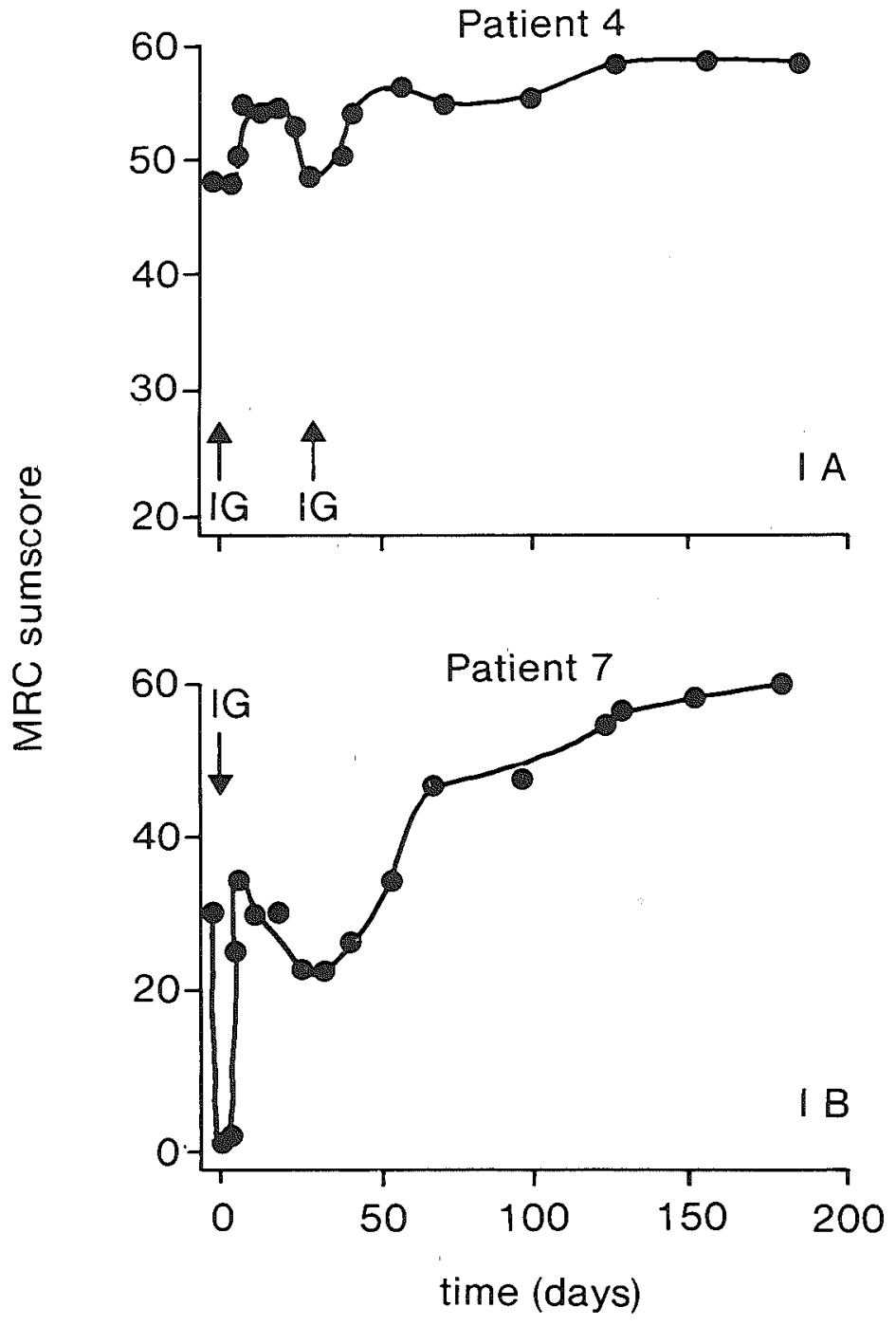

Figure 6.1. Clinical course, measured by the MRC-sumscore of patient $4(A)$ and patient 7 (B). 

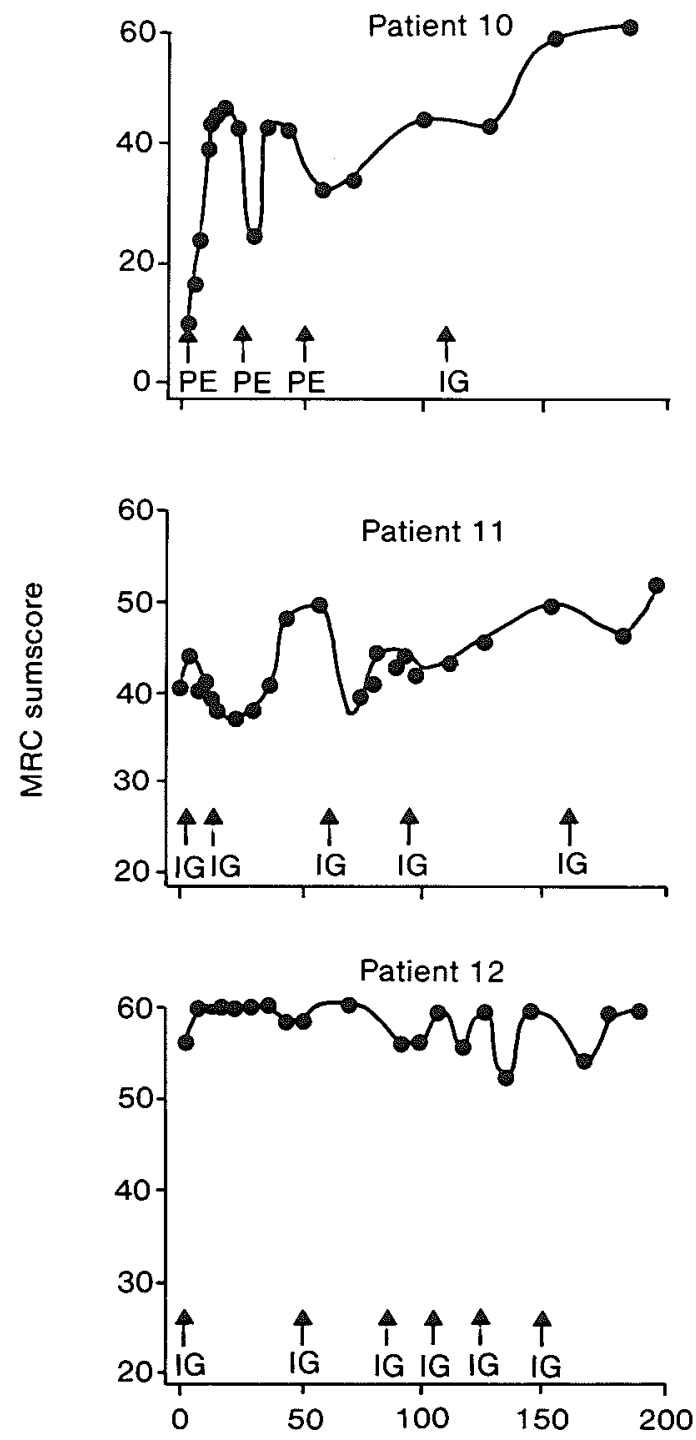

Figure 6.2. Clinical course, measured by the MRC-sumscore of three patients (10, 11 and 12) needing more than one retreatment. 
Three patients $(10-12), 1$ in the PE group and 2 in the IgIv group, required several treatment courses (Figure 6.2). The fluctuations in MRCsumscore were often accompanied by changes in functional score. Duration of signs prior to treatment in this group had been 4,10 and 14 days respectively. Patient 10 received a total of $3 \mathrm{PE}$ treatment courses, and finally, after a third relapse she refused any further PE. Instead she received IgIv, after which she again showed improvement. She has had no further relapses to date ( 28 months since her last treatment). Patient 11 was treated five times with IgIv after which she achieved almost complete recovery without further relapses for 16 months after the last treatment. The third patient in this group, patient 12 , has been treatment dependent for 12 months. During the follow-up period in the clinical trial, he received 6 courses of treatment with IgIv, each time with succes. This patient is now considered to have CIDP, not GBS.

\section{Discussion}

Of hundred Guillain-Barré patients, treatment related fluctuations occurred in 12\% (95\% confidence limits: $8-20 \%$ ); 5 of 49 patients in the PE group and 7 of 51 patients in the IgIv group. This is in agreement with the results of both Osterman [133] and Ropper [143] who reported secondary deteriorations after $\mathrm{PE}$ in 16 and $11 \%$ respectively. The fluctuations in GBS patients treated with PE, are considered to support strongly the biological effectiveness of the treatment and provide further confirmation of the outcome of several trials showing a beneficial effect of PE [50, 61]. We have now shown that this phenomenon occurs alike in patients randomly treated with either PE or IgIv. The effect of IgIv in GBS has only recently been suggested in a pilot study [88]. This new observation of similar therapy related fluctuations in both treatments indirectly supports our earlier suggestion that the beneficial therapeutic effect of IgIv might be similar to that of PE. In case of a relapse after a response to treatment it is conceivable that the pathogenetic process, which is suppressed by PE or IgIv, is still active or reactivated after therapy. One reason why this occurs in only a minority of patients, might be that these patients are treated earlier in the course of the disease so that the active disease phase is not yet over at the end of treatment. In one study, the group of relapsing patients was treated slightly earlier in the disease course [143]. In another study only some patients who were exchanged rapidly within 5 days using a continuous flow technique relapsed, whereas no patients relapsed who were exchanged over a period of 7-13 days using an intermittent flow technique [133]. Furthermore, in our patients with a 
fluctuating course, the duration of disease prior to initiation of treatment was very short ( 3 - 8 days; median 4 days).

In some other patients, the active phase of the disease seemed to be much longer than generally assumed. This may be concluded from the clinical course in the patients who required several treatments. One might argue that this prolongation of the active phase of the disease is induced by treatment. This, however, is unlikely as it occurs too infrequently to be a generally occurring mechanism. Moreover, long duration of the active disease process might have been common in the pretreatment days, but at that time it would not have been easily detected; either a long active phase or axonal degeneration may cause a long plateau phase, which cannot always be distinguished.

Two of the patients (10 and 11, Figure 6.2), who had a more prolonged treatment related fluctuating course, ultimately made a good recovery without relapses during the follow-up period of 28 and 16 months, respectively. In the third patient, showing a relapsing and remitting course, the initial diagnosis had to be changed from GBS to CIDP, the onset of which may sometimes be subacute [112]. This patient now receives chronic therapy, which is successful, with smaller doses of IgIv at regular intervals as has been reported before [42, 179, 185].

Not all patients with secondary deterioration need additional treatment. We saw three patients who improved spontaneously following their relapse, confirming the observations of Ropper [143]. There was no difference between them and the other patients, and they showed a comparable clinical course with those patients who received a second course of treatment. At present, however, it is not possible to predict how long deterioration will proceed and therefore it is difficult to withhold a second treatment if a patient has responded well and is deteriorating again.

In conclusion, the earlier results suggesting a beneficial response of IgIv in GBS patients is supported by the present report about a treatment related fluctuating course in some patients following IgIv. Currently, in the Netherlands, a multicentre trial is being carried out to compare IgIv with $\mathrm{PE}$ in 200 patients. The results of this trial should be awaited before deciding to apply IgIv routinely in severe GBS patients. However, in those GBS patients who need treatment and in whom PE is contraindicated, IgIv would seem to be an alternative. 


\section{CAMPYLOBACTER JEJUNI/COLI INFECTION AND THE GUILLAIN-BARRÉ SYNDROME}

\section{Introduction}

In about two-thirds of patients with Guillain-Barré syndrome (GBS), this disorder is preceded by an infection, usually an upper respiratory infection and to a lesser extent a gastrointestinal infection [86, 113, 120, 154]. In controlled studies a relationship between GBS and cytomegalovirus (CMV) infection was found by Dowling [37] and Winer [191] in 15\% and $11 \%$ of GBS patients, respectively. Furthermore, Dowling [37] showed an association of Epstein-Barr virus (EBV) and GBS in $8 \%$ and Goldschmidt of Mycoplasma pneumoniae and GBS in 5\% of the patients [56]. Winer [191], however, found no relationship between either EBV or Mycoplasma pneumoniae and GBS. Many other organisms have been described in association with GBS but these associations appear to be coincidental [3, 37, 73].

Recently, infection with Campylobacter jejuni/coli (CJC) has increasingly been linked to GBS. This Gram negative bacterium is now increasingly recognized as a leading cause of gastroenteritis in man [11]. Under special circumstances this bacterium can be isolated and grown from faeces during the first two to three weeks after onset of the gastroenteritis [11]. A CJC infection is diagnosed either by isolation from faeces or by serological studies.

Since 1982, several patients have been described, with GBS occurring shortly after CJC infection (Table 7.1).

Kaldor [82], in a retrospective, serological study showed that $38 \%$ of 56 GBS patients had a CJC infection preceding GBS.

In a prospective serological study, CJC infection preceded GBS in $14 \%$ [191]. As in most case reports, GBS following CJC infection was rather severe in these two studies $[82,191]$. However, other factors that are now considered to be of prognostic importance such as age, time taken to become unable to walk independently, respiratory status and small or absent compound muscle action potentials (CMAP) after distal stimulation, were not taken into account $[114,190]$. Finally, patients were treated with plasma exchange or corticosteroids which are likely to have influenced outcome [191]. 
TABLE 7.1

REPORTS OF CAMPYLOBACTER JEJUNI/COLI ASSOCIATED GUILLAIN-BARRÉ SYNDROME

\begin{tabular}{|c|c|c|c|c|c|c|c|}
\hline Source & year & age & int. $^{\mathrm{a}}$ & localisation & outcome & serol. ${ }^{\mathrm{d}}$ & culture \\
\hline Rhodes [139] & '82 & 45 & 15 & extr. & poor at $8 \mathrm{~m}$ & + & + \\
\hline Molnar [122] & '82 & 42 & 9 & extr. & poor & - & + \\
\hline Constant [27] & '83 & 34 & 8 & $\mathrm{cn}^{c}+$ extr. & poor & - & + \\
\hline Wroe [192] & '84 & 27 & 7 & cn + extr. & good at $2 \mathrm{~m}$ & - & + \\
\hline Speed [163] & '84 & 16 & 10 & $?$ & poor & el+ & + \\
\hline Pryor [38] & '84 & 34 & 21 & extr. & good at $2 \mathrm{~m}$ & - & + \\
\hline Pryor & '84 & 22 & 21 & cn + extr. & good at $2 \mathrm{~m}$ & - & + \\
\hline de Bont [33] & '86 & 2 & 9 & $\mathrm{cn}+$ extr. & good at $7 \mathrm{~m}$ & - & + \\
\hline Kohler [92] & '87 & 69 & 13 & extr. & poor & - & + \\
\hline Sovilla [162] & '88 & 38 & 6 & extr. & poor at $1 y$ & - & + \\
\hline Sovilla & '88 & 81 & 5 & extr. & good at $9 \mathrm{~m}$ & - & + \\
\hline Sovilla & '88 & 60 & 9 & extr. & good at $1 y$ & cft & $n d^{e}$ \\
\hline Ropper [144] & '88 & 63 & 6 & extr. & poor & - & + \\
\hline Ropper & '88 & 74 & 8 & cn + extr. & good at $6 \mathrm{~m}$. & - & + \\
\hline Ropper & '88 & 32 & 7 & extr. & good at $6 \mathrm{~m}$. & - & + \\
\hline Ropper & '88 & 19 & 10 & extr. & good at $2 \mathrm{~m}$. & - & + \\
\hline
\end{tabular}

\footnotetext{
a int. = interval between first neurological complaints and admission to the study in days

b extr. $\quad=$ extremities

c cn. = cranial nerves

d serol. = serological study; el. = elisa; cf. = complement fixation

e nd. $\quad=$ not done
}

At present a multicentre trial is in progress in the Netherlands comparing plasma exchange (PE) with high-dose immunoglobulins (IgIv) in GBS patients. In this prospective study, we have looked for evidence of a recent CJC infection and a possible relationship between CJC infection and the severity of GBS in the first 100 patients.

\section{Patients and methods}

The first hundred patients from the Guillain-Barre trial were included in this study. Forty-eight were randomized to plasma exchange (200-250 ml $/ \mathrm{kg}$ in $10-14$ days $)$ and 52 to high dose immunoglobulins $(0.4 \mathrm{~g} / \mathrm{kg} / \mathrm{day}$ for 5 consecutive days, Gammagard ${ }^{R}$, Baxter). At entry, none of the 
patients was able to walk independently. All were randomized within two weeks of onset of the disease.

Serum samples taken before treatment and 2, 4, 14 and 26 weeks later, were divided into small aliquots and frozen at $-20^{\circ} \mathrm{C}$. All first serum samples were examined for antibodies to $\mathrm{CJC}$ by the counterimmunoelectropheresis technique (CIE) described in detail by Bänffer [8]. A titre of 1:8 or higher is taken as evidence of a recent infection. Hundred healthy age- and sex-matched blood-bank donors served as controls.

In addition, sera were analysed with a complement fixation test (CFT) described by Mosimann [123]. Serum from the first 70 patients was also tested for antibodies to Yersinia, Shigella and Salmonella.

The presence of the HLA-B27 antigen was assessed in 5 patients with positive CIE CJC tests and admitted to our own department.

All initial serum samples were examined for evidence of a recent infection with CMV, EBV, hepatitis A and B, Mycoplasma pneumoniae, influenza, parainfluenza, adenovirus, mumps, measles, herpes simplex and varicella zoster. IgM antibodies to CMV and EBV were determined by immunofluorescence; to Hepatitis A and B using an ELISA assay. The other tests were complement fixation assays.

According to a predefined schedule, clinical assessment of the patients was performed three times a week for the first few weeks, the frequency gradually decreasing to once a month at the end of the 6 month follow-up period. The functional score (Table 2.1) was determined, during each visit. The severity of GBS in the CJC positive and negative group was assessed by comparing: 1 . the proportion of patients who showed improvement in functional score at 4 weeks as compared to randomization, 2. time until 1 grade of functional improvement and 3. time until walking unaided (functional grade 2) was possible again. Neurophysiological studies were performed at randomisation, after one week and after 1 month. Of interest for this study is the measurement of the CMAP of the abductor digiti quinti after distal stimulation of the ulnar nerve at the wrist, since it has been claimed that this parameter has prognostic value $(114,121,190]$.

\section{Statistical methods}

Proportions of patients who improved at 4 weeks were compared with the chi-square test. Time-dependent events, such as time until 1 functional grade recovery and time until functional grade 2 is reached, were analysed using Kaplan-Meier curves and the logrank test. Multivariate analyses, for analysing 2 or more prognostic factors simultaneously, was performed using logistic regression for dichotomous end points and Cox's proportional hazards model when censored times were compared. 


\section{Results}

A recent CJC infection (i.e. a CIE titre of 1:8 or higher) was present in $38 \%$ of GBS patients and in $13 \%$ of the controls ( $p<0.001 ; 95 \%$ confidence limits of the difference $12-38 \%$ ). The titres of the 38 patients with recent infection were generally higher than those of the 13 controls (Table 7.2).

\section{TABLE 7.2 .}

NUMBER OF GBS PATIENTS AND CONTROLS WITH RECENT CJC INFECTION AND THEIR TITRE IN THE CIE

\begin{tabular}{rcc}
\hline Titre & Patients & Controls \\
\hline $1: 128$ & 2 & 0 \\
$1: 64$ & 0 & 0 \\
$1: 32$ & 10 & 1 \\
$1: 16$ & 11 & 5 \\
$1: 8$ & 15 & 7 \\
\hline
\end{tabular}

Of the 38 patients with a serologically proved CJC infection, only 13 suffered from a gastroenteritis. Five reported influenza-like symptoms, 7 had suffered from a common cold and 12 had had no complaints at all. Of the 62 patients without a serologically proved CJC infection, 9 had suffered from gastroenteritis. Two of these gave a positive complement fixation test for CJC, 1 of them also had evidence of a recent Yersinia infection. Other concurrent infections occurred in the group with a CJC infection in 11 patients (29\%), predominantly CMV (7 patients); in the group without a CJC infection, a similar percentage had concurrent infections (25\%; 7 with CMV).

None of the 5 CJC positive patients tested had HLA-B27 antigen.

$C J C$ infection and severity of $G B S$

Four weeks after randomisation, $21 \%$ of the patients with a CJC infection had improved at least 1 functional grade versus $56 \%$ in the group without a CJC infection ( $\mathrm{p}<0.001 ; 95 \%$ confidence limits of the difference: $17-53 \%)$. Median time to improve 1 functional grade was 27 days in the group without a CJC infection and 69 days in the group with CJC infection 
( $\mathrm{p}<0.001$; Figure 7.1). Median time to improve to functional grade 2 was 34 days in the group without and 125 days in the group with a CJC infection ( $p<0.001$; Figure 7.2).

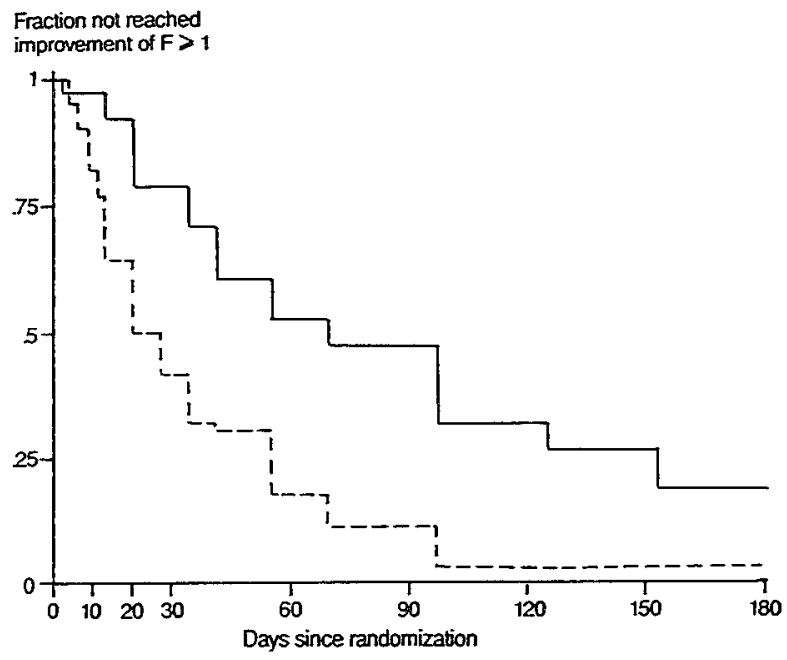

Figure 7.1 Fraction of patients who did not improve 1 or more functional grades. The curve with the dashed lines represents patients without CJC infection, and the other curve patients with a CJC infection

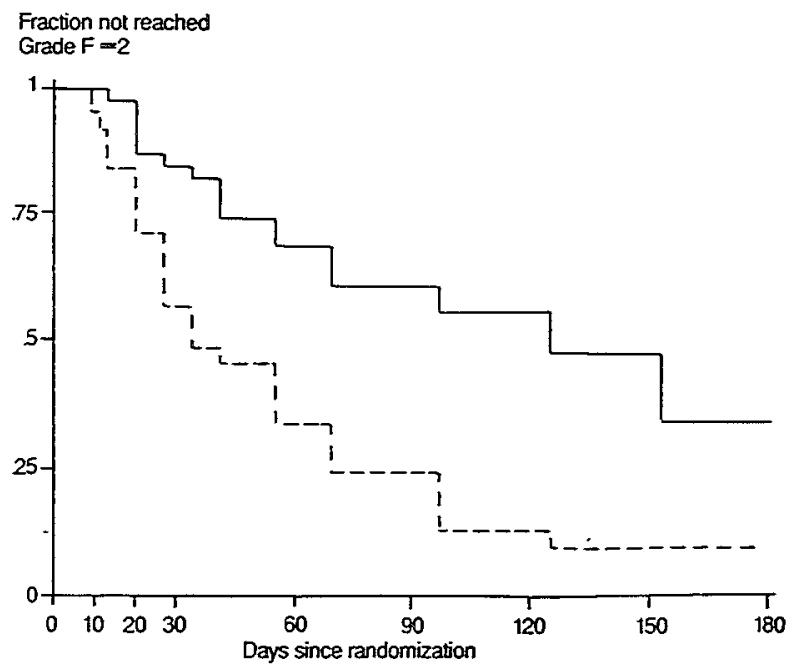

Figure 7.2 Fraction of patients who did not reach functional grade 2 (walking independently). The curve with the dashed lines represents patients without CJC infection, and the other curve patients with a CJC infection. 
Some patient characteristics such as: age, duration of disease prior to randomisation, CMAP of the abductor digiti quinti after distal stimulation of the ulnar nerve, are presented in Table 7.3.

\section{TABLE 7.3}

PATIENT CHARACTERISTICS

\begin{tabular}{|c|c|c|}
\hline & $\begin{array}{l}\text { Patients with } \\
\text { CJC infection }\end{array}$ & $\begin{array}{l}\text { Patients without } \\
\text { CJC infection }\end{array}$ \\
\hline Age: mean (range) & 49 y $(10-78)$ & 47 y $(9-80)$ \\
\hline $\begin{array}{l}\text { Duaration of disease } \\
\text { until admission } \\
\text { mean (range) }\end{array}$ & $\begin{array}{l}5 \text { days } \\
(0-14)\end{array}$ & $\begin{array}{l}6 \text { days } \\
(0-14)\end{array}$ \\
\hline $\begin{array}{l}\text { CMAP of abductor digiti } \\
\text { quinti after distal sti- } \\
\text { mulation on admission; } \\
\text { mean (range) }\end{array}$ & $\begin{array}{c}6.7 \mathrm{mV} \\
(0.1-28)\end{array}$ & $\begin{array}{c}6.8 \mathrm{mV} \\
(0.1-18)\end{array}$ \\
\hline
\end{tabular}

After correction for different variables (treatment, CMAP, age, time of disease prior to admission), differences of disease severity remained significant for all factors (for improvement at 4 weeks: $p<0.01$; for time to improve 1 functional grade: $\mathrm{p}=0.01$; for time to reach functional grade $2: \mathrm{p}=0.03$ ).

A detailed report about the interaction of all variables on the prognosis of the disease will be presented after completing the trial.

\section{Relationship between persisting CJC titre and clinical recovery}

In 29 patients with a CJC infection, serum taken 3 and 6 months after randomization was available. A titre of $1: 8$ or higher was present 3 months after randomisation in 9 patients and after 6 months in 6 patients. Some patients with a titre of $1: 8$ or higher at 6 months were at that time still bedor chairbound while others, with a titre of the same level at 6 months, had already recovered completely. 


\section{Discussion}

The observed frequency of CJC in this prospective study of 100 GBS patients amounts to $38 \%$ (95\% confidence limits $28-48 \%$ ). This is in accordance with a retrospective study by Kaldor [82]. Winer [191], in a prospective study, found a lower rate $(14 \%)$. The relatively high rate of infection in our controls is remarkable and unexplained. Patient and control sera were tested simultaneously in the same laboratory by the same method. One might argue that there should be a titre of at least 1:32 to conclude the presence of a recent CJC infection: then the frequency of CJC in GBS patients is $12 \%$ and in controls $1 \%$. A titre of $1: 32$ to discriminate between infected and non infected patients is, however, in contrast to earlier reports about the CIE from the same laboratory [8]. Stool cultures are no alternative since they are only positive up to 2-3 weeks after onset of gastrointestinal complaints [11]. GBS symptoms usually start with a delay of about 2-3 weeks after the infection; hence, the diagnostic yield will be low. We prefer, therefore, to adhere to the previously established diagnostic titre of $1: 8$, and to regard the relatively high positive score in the controls as evidence of a recent CJC infection. Not all patients with CJC infection have necessarily had gastrointestinal complaints ([82] and this study). The reverse is also true; not all patients with a gastroenteritis have a CJC infection. We found no other specific gastrointestinal infection in the majority of these patients. Remarkably, other infections (including CMV infection) occurred as often in the CJC positive group as in the CJC negative group. This observation lends support to the dual infection hypothesis as a triggering mechanism [188]. CJC infection has been linked to a more severe form of GBS [82,191]. These studies, however, did not take other prognostic factors into account. It has been shown that: low CMAP after distal stimulation, age over 40, short duration between disease onset and inability to walk unaided, and need for ventilatory support on admission, are all associated with a poor outcome [114, 121, 190].

In our study CJC infection was associated with a poorer prognosis considering the percentage of patients who had improved at 4 weeks, time to improve one functional grade and time to reach independent walking. In the CJC infected group fewer patients were ventilated on admission (11 and 19\%, respectively).

After correction for the other prognostic factors, significance remained. A more general comment on these prognostic factors should be made. Certain factors, like a short duration between onset of the disease and inability to walk unaided, early need for ventilatory support and a low CMAP, are interrelated variables describing the fulminant course of the 
disease. We suggest to call these factors: "associated" prognostic factors. Age and, according to this study, Campylobacter infection may be called "independent" prognostic factors. Such "independent" factors are pathogenetically important. Both "independent" and "associated" factors are important for assessing the prognosis of the individual patient.

The pathogenesis of GBS after CJC infection is not clear. No special serotype of CJC has been linked to GBS, and a GBS variant such as the Fisher syndrome has also been described following CJC infection [91]. Furthermore, GBS has occasionally been described after other enteric infections such as Yersinia [44] and Salmonella [155]. There may be several pathogenetic mechanisms. A well known complication of CJC infection and also Yersinia infection is aseptic arthritis related to the HLA-B27 histocompatibility antigen $[96,44]$. In patients with GBS after CJC infection, however, this does not seem to play a role, as GBS is not linked to a special HLA A or B type [83, 167], and 5 patients with CJC infection in this study were HLA-B27 negative.

Immunological cross reactivity might occur between CJC and peripheral nerve components. Antigenic similarities have been described between myelin constituents and virus [79], and also between brain components and bacteria causing meningitis [49]. Another possibility may be direct neural damage by enterotoxins. CJC has recently been shown to produce a cholera-like enterotoxin [148] that possibly binds to gangliosides like the cholera toxin itself [182].

In conclusion: CJC infection precedes GBS in a considerable number of patients and is now the most frequently occurring antecedent infection. CJC infection is also linked to a more severe form of GBS with a relatively slow recovery, also after correction for other prognostic variables. 


\section{GENERAL SUMMARY AND CONCLUSIONS}

The aim of this study was to investigate a new, and relatively simple treatment for patients with Guillain-Barré syndrome (GBS).

In chapter 1, some general aspects of GBS are discussed.

The main signs of the disorder are reflected in a list with diagnostic criteria; this is used throughout the world. The diagnosis GBS is made with reference to this list.

Inflammation of the peripheral nerves, leading to paresis or paralysis of arms and legs, is the hallmark of the syndrome. In some patients, weakness develops in facial muscles or in respiratory muscles requiring artificial ventilation. Myotatic reflexes are low or absent and sensory disturbances may occur. After a progressive phase, a plateau phase follows with subsequent recovery that may take months to years, and which is sometimes incomplete. In this chapter we also discuss that severe pain may occur, especially in the first stage of the disease, and may lead to a wrong diagnosis. There is no explanation for this severe pain.

Areflexia is one of the main disease criteria. We noticed, however, that despite considerable weakness reflexes may be present for a long time when sensation is not impaired. This may also wrongly raise doubts about the diagnosis of GBS.

In about $2 / 3$ of the patients, GBS is preceded by upper respiratory or gastrointestinal infections. A relationship between cytomegalovirus and Campylobacter jejuni/coli and GBS has been established. The pathogenesis of GBS is unknown. There are indications that cellular but also humoral immunological mechanisms may play an important role.

The weakness is caused by nerve conduction block, expressed by a decrease in the compound muscle action potential after stimulation. The distribution of conduction block varies between individual patients. For a long time, decrease of nerve conduction velocity received much attention. This decrease is presumably a reflection of de- and remyelination that occurs late in the disease. In the early stage, nerve conduction velocity can be normal, despite severe weakness.

General supportive care with reference to feeding, ventilation, prevention of thrombosis and decubitus, and protection against pressure palsies is of primary importance during treatment. Apart from this, a continuous search is going on for possible ways of influencing the disease process itself. On the basis of results of some large studies, plasma exchange (PE) is now 
generally accepted as a treatment for GBS. PE is, however, an intensive therapy with some drawbacks. For this reason, and because of the effects of intravenously administrated immunoglobulins (IgIv) in other immunological disorders, it was decided to compare IgIv with PE in a multicentre trial. The design of this trial together with a number of preparative studies form the basis of this thesis.

Chapter 2 describes the study of the natural history of GBS in 18 children and 50 adults. The severity of the disease, expressed as: 1 . the number of patients who require artificial ventilation; 2 . the duration of artificial ventilation; 3. the duration of stay in hospital and rehabilitation centre; and 4 . the degree of recovery after 1 and 2 years does not differ significantly in the two groups. On these grounds we conclude that there are no arguments that GBS in children has a more favourable course compared to adults. Therefore PE should be considered in children as well as in adults with GBS.

In chapter 3, the first 8 GBS patients treated with IgIv are described. Two of them were initially successfully treated with PE but then deteriorated again. Subsequently they were treated with IgIv or fresh frozen plasma with the same favourable response as observed after PE. Four other patients showed a clear improvement after IgIv. Only two showed no response; they had severe axonal degeneration with very slow recovery. These results led to the hypothesis that IgIv is as effective as PE.

Chapter 4 presents the results of a study in which 2 different methods for scoring patients are compared. One method, the functional or $\mathrm{F}$ score, classifies the patient according to a ordinal validity scale. There are 6 classes predominantly based on locomotor function (Table 2.1). The other method, the MRC-sumscore which is developed in the pilot study, gives a general impression of muscle strength. Six muscle groups on both sides are scored according to the 5 point scale of the Medical Research Council. After summation of these scores, the MRC-sumscore runs from 0 (paralytic) to 60 (normal).

In patients who are bed- or chairbound or artificially ventilated, the MRCsumscore adds valuable information, while the $F$ score is insensitive. In relatively strong patients the $\mathrm{F}$ score is more sensitive. This chapter also points out that when different neurologists use the two methods in the investigation of the patient, they often come to the same conclusions. If the same investigator is coupled to different neurologists and they score 60 patients using both methods, then agreement, corrected for change (kappa), for the F score is 0.85 and the intraclass correlation coefficient for 
the MRC-sumscore is 0.96 . In this situation regular feed back is given. Furthermore, 10 residents of the neurology department examined 60 patients in randomly compiled couples. In that situation, the kappa for the F score was 0.80 and the intraclass correlation coefficient for the MRCsumscore was 0.93 . The main conclusion is that both methods are complementary and have a high interobserver agreement making them suitable for use in multicentre studies.

The design of the Dutch Guillain-Barre trial is described in chapter 5. In this randomised trial, treatment with IgIv is compared with PE in GBS patients. The effect of PE has been demonstrated in several large studies. It is, however, a cumbersome procedure with complications and contraindications and furthermore not widely applicable. These disadvantages do not apply to IgIv which is also safe, especially with regard to transmission of HIV and hepatitis. Hence, if both treatments are equally effective, IgIv will be preferable to PE. A trial that intends to demonstrate equivalence is called a conservative trial. Assuming the chance of making a type 1 error is $5 \%$ and of a type 2 error $20 \%$, one must investigate 200 patients. Nineteen neurological centres are cooperating in this trial which started in October 1986. Two interim analyses were planned, one after 100 and one after 150 patients. The first was carried out in 1989. The criteria to stop the study were not met at that stage.

After follow-up of the first 100 patients in the trial, it appeared that about $10 \%$ of the patients relapsed following an initial improvement after therapy. These patients are described in chapter 6 . They were equally divided between the two treatment groups. Most of them were successfully retreated. It is assumed that in these cases the disease process is active for a longer period than the relatively short time in which IgIv or PE exert their effect. These treatment related fluctuations are considered to be an extra argument for the biological effect of the treatment.

Finally chapter 7 describes the occurrence of Campylobacter jejuni/coli (CJC) infections preceding GBS, and the relationship between such an infection and the severity of GBS. In the first 100 patients of the trial this infection was present in $38 \%$ of the patients, compared to $13 \%$ of healthy controls; this is a significant difference. Furthermore, a recent CJC infection is related to a more severe GBS as reflected by; 1 . a smaller percentage of patients who recover at least 1 functional grade after 4 weeks; 2. a prolonged time to improve 1 functional grade; and 3. a prolonged time before they can walk independently.

It is not known why CJC infection leads to a more severe form of GBS. 


\section{Conclusion}

Plasma exchange can favourably influence the natural history of GBS. Disease duration is reduced, but it is still uncertain whether the ultimate outcome of GBS is also improved. IgIv may be a promising alternative but routine clinical application should await the result of the Dutch GuillainBarré trial.

There are several problems in planning treatment with PE or IgIv in GBS patients. Some patients clearly respond after treatment with PE or IgIv, while others do not. However, one does not know in advance whether a particular patient will respond to treatment.

Furthermore, it is difficult to assess the correct moment to start treatment. Early in the disease it is not always clear whether a patient will suffer from a severe or a very slight form of GBS. The effect of PE, however, is especially present in patients treated early in the course of their disease. As a compromise, in the Dutch Guillain-Barré trial patients are treated when they are no longer able to walk independently.

Recently, several prognostic factors have been identified. Some of these, however, such as duration of disease until the patient can no longer walk independently, compound muscle action potential after distal stimulation and the early need for artificial ventilation are themselves reflections of the severity of the disease and should perhaps be called "associated" prognostic factors. At the moment, only age and a recent Campylobacter jejuni/coli infection are known to be "independent" variables. It is not known to what extent these factors determine the response to treatment. In the near future, it is necessary to search for factors that identify responders. Future research should also be directed at the mechanism by which IgIv exerts its effect in GBS. 


\section{SAMENVATTING}

Het doel van dit proefschrift is het onderzoeken van een nieuwe, relatief eenvoudige, behandelingsmogelijkheid voor patiënten met het syndroom van Guillain-Barré.

In hoofdstuk 1 worden een aantal algemene aspecten van het syndroom van Guillain-Barré besproken.

De belangrijkste verschijnselen zijn weergegeven in een, wereldwijd gehanteerde, lijst met criteria op grond waarvan kan worden vastgesteld of iemand het syndroom heeft.

$B i j$ het syndroom van Guillain-Barré is sprake van een ontsteking van de perifere zenuwen die leidt tot verlamming van armen en benen. Soms treedt ook een verlamming van de spieren in het gelaat op of van de ademhalingsspieren waarvoor tijdelijk beademing noodzakelijk is. De spierrekkingsreflexen zijn verlaagd of afwezig en vaak zijn er ook gevoelsstoornissen. $\mathrm{Na}$ een periode van verslechtering volgt een stationaire fase waarna het herstel begint dat echter lang kan duren en niet altijd volledig is. In dit hoofdstuk wordt verder beschreven dat hevige pijn nogal eens voorkomt, met name in het begin van de ziekte en aanvankelijk kan leiden tot een andere, verkeerde diagnose. Een duidelijke verklaring voor die heftige pijn is er niet.

Hoewel afwezigheid van reflexen een van de belangrijkste verschijnselen van het syndroom is, is het ons opgevallen dat, ondanks aanmerkelijk zwakte, de reflexen, met name bij een normaal gevoel, langdurig aanwezig kunnen blijven. Ook dit kan ten onrecht aanleiding zijn aan de diagnose syndroom van Guillain-Barré te twijfelen.

Het syndroom van Guillain-Barré wordt in ongeveer $2 / 3$ van de gevallen vooraf gegaan door een infectie, meestal van de bovenste luchtwegen of het maagdarmkanaal. Met name voor cytomegalovirus en Campylobacter jejuni/coli infectie is een relatie met het syndroom van Guillain-Barré aangetoond.

De pathogenese van het syndroom van Guillain-Barré is onbekend. Er zijn aanwijzingen dat zowel cellulaire, doch met name ook humorale immunologische mechanismen een rol spelen.

De oorzaak van de zwakte is blokkade van de zenuwgeleiding in de motore zenuwvezels. Het lijkt dat bij sommige patiënten deze blokkade meer diffuus verspreid over de zenuw voorkomt en bij andere patiënten meer distaal in de zenuw. In dit laatste geval zijn naast de motore vezels ook 
steeds de gevoelsvezels aangedaan. Ten onrechte werd vroeger voornamelijk aandacht geschonken aan de zenuwgeleidingssnelheid die voornamelijk iets lijkt te zeggen over laat optredende de- en remyelinisatie, en in het begin normaal kan zijn ondanks ernstige zwakte.

Algemeen ondersteunende maatregelen met betrekking tot de voeding, ademhaling, trombose en decubitis preventie en bescherming tegen lokale drukneuropathieen zijn van primair belang tijdens de behandeling. Daarnaast wordt steeds gezocht naar mogelijkheden het ziekteproces zelf te beinvloeden. Plasma-uitwisseling is tot nu toe de enige mogelijkheid. $\mathrm{Na}$ enkele grote studies is nu algemeen aanvaard dat deze behandelingsvorm aangewezen is als therapie voor het syndroom van Guillain-Barré. Dit is echter een intensieve behandeling waaraan een aantal nadelen zijn verbonden. Om deze reden worden, naar aanleiding van het effect bij andere immunologische aandoeningen, intraveneus toegediende immuunglobulinen (IgIv) als nieuwe behandeling in een multicentre trial vergeleken met plasma-uitwisseling.

De opzet van deze trial, samen met enkele voorbereidende studies vormen de basis van dit proefschrift.

In hoofdstuk 2 wordt de studie beschreven naar het spontane beloop van het syndroom van Guillain-Barré bij 18 kinderen en 50 volwassenen. De ernst van de ziekte, uitgedrukt als: 1 . het aantal patiënten dat beademing nodig heeft; 2 . de duur van de beademing; 3 . de duur van verblijf in ziekenhuis en revalidatie-centrum en 4; de mate van herstel na 1 en 2 jaar is in beide groepen niet significant verschillend. Op grond van deze gegevens wordt geconcludeerd dat er geen aanwijzingen zijn dat het syndroom van Guillain-Barré bij kinderen gunstiger verloopt dan bij volwassenen en dat zij net als volwassenen voor specifieke behandeling in aanmerking komen.

In hoofdstuk 3 worden de eerste 8 Guillain-Barré patiënten beschreven die behandeld werden met IgIv. Twee van hen werden in eerste instantie behandeld met plasma-uitwisseling doch gingen daarna opnieuw achteruit. $\mathrm{Zij}$ werden in tweede instantie behandeld met IgIv, met eenzelfde gunstig resultaat als na plasma-uitwisseling. Vier andere patiënten toonden een duidelijke vooruitgang na IgIv. Slechts twee reageerden niet op IgIv; zij hadden ernstige axonale beschadigingen waardoor het herstel zeer traag was. Deze resultaten leidden tot de hypothese dat IgIv even effectief is als plasma-uitwisseling.

Hoofdstuk 4 geeft de resultaten weer van de studie waarin twee verschillende methoden om de patiënten te scoren worden vergeleken. Bij de ene methode, de functionele of $\mathrm{F}$-score, wordt de patiënt geclassificeerd volgens een ordinale validiteitsschaal. Er zijn 6 klassen voornamelijk geba- 
seerd op de loopfunctie (zie tabel 2.1). De andere methode, de MRCsomscore die in deze studie is ontwikkeld, geeft een algemene weergave van de spierkracht. Hiertoe worden zowel rechts als links 6 spiergroepen gescoord volgens de 5 puntschaal van de Medical Research Council; opgeteld geeft dit een score van 0 (totaal verlamd) tot 60 (normaal). Bij bedlegerige - , rolstoel- en beademde patiënten geeft de MRC-somscore waardevolle aanvullende informatie en is de F-score ongevoelig. Bij relatief sterke patiënten is de F-score gevoeliger. Verder wordt in dit hoofdstuk beschreven dat, wanneer verschillende neurologen beide methodes bij het onderzoek van de patiënt gebruiken zij vaak tot dezelfde conclusie komen. Wanneer 1 vaste onderzoeker met steeds een andere neuroloog 60 patiënten met beide methoden scoort en daar regelmatig feed back over geeft is de, voor kans gecorrigeerde, overeenstemming (kappa) voor de Fscore 0.85 en de intraclass-correlatie-coefficient voor de MRC-somscore 0.96 . Tevens werden 10 arts-assistenten in opleiding tot neuroloog ingedeeld in steeds wisselende, aselect, samengestelde koppels. Wanneer deze koppels in totaal 60 patiënten scoren is de kappa voor de F-score 0.80 en de intraclass-correlatie-coefficient voor de MRC-somscore 0.93. De slotconclusie is dat beide scorings methoden elkaar goed aanvullen en een zeer goede "inter observer agreement" hebben waardoor zij zeer geschikt zijn voor " multicentre" studies.

De opzet van de Nederlandse Guillain-Barré trial wordt beschreven in hoofdstuk 5 . In deze gerandomiseerde trial wordt bij Guillain-Barré patiënten de behandeling met IgIv vergeleken met plasma-uitwisseling. Van plasma-uitwisseling is het effect in diverse grote studies aangetoond. Het is echter een lastige behandeling met complicaties en contraindicaties, die bovendien niet in elk ziekenhuis kan worden toegepast. Deze nadelen gelden nauwelijks voor IgIv, dat met name ook veilig is met betrekking tot eventuele besmetting met HIV of hepatitis virus. Als beide behandelingen even effectief blijken te zijn, zal IgIv daarom de voorkeur verdienen boven plasma-uitwisseling.

Een trial die gelijkwaardigheid wil aantonen heet een conservatieve trial. Uitgaande van de kans op een type 1 fout van $5 \%$ en een type 2 fout van $20 \%$ zijn tenminste 200 patiënten nodig. 19 neurologische centra verspreidt over Nederland werken in dit onderzoek samen. In oktober 1986 is de trial gestart. Er zijn twee interim analyses gepland nl. bij 100 en 150 patiënten. De eerste vond plaats in 1989; het "stopcriterium" werd toen niet bereikt en de trial is volgens plan voortgezet.

Nadat de eerste 100 patiënten in de trial gevolgd waren, bleek dat bij ongeveer $10 \%$, na een aanvankelijke verbetering na behandeling, een tweede achteruitgang plaats vond. Deze patiënten worden beschreven in hoofdstuk 6 . Deze patiënten waren gelijk verdeeld over beide behandelings- 
groepen. De meesten van hen werden opnieuw met succes behandeld. Men neemt aan dat in die gevallen het ziekte proces langer actief is dan de relatief korte tijd waarin IgIv of plasma-uitwisseling effect sorteren. Deze door de behandeling geinduceerde fluctuaties worden beschouwd als een extra argument voor het biologische effect van de behandeling.

In hoofdstuk 7 tenslotte wordt het onderzoek beschreven naar het voorkomen van een infectie met Campylobacter jejuni/coli (CJC) kort voor de neurologische verschijnselen en de relatie tussen deze infectie en de ernst van het syndroom van Guillain-Barré. Bij de eerste 100 patiënten uit de trial blijkt in $38 \%$ sprake van deze infectie en bij gezonde controle personen in 13\%; dit is een significant verschil. Verder is een recente CJC infectie gerelateerd aan een ernstiger beloop van het syndroom van Guillain-Barré wat zich uit in: 1 . kleiner percentage patiënten dat minstens 1 functionele graad hersteld is 4 weken na opname in het onderzoek; 2 . een langere duur tot 1 graad functioneel herstel; en 3. een langere duur tot weer zelfstandig kunnen lopen. 


\section{REFERENCES}

1. Albers JW, Donofrio PD, McGonagle TK. Sequential electrodiagnostic abnormalities in acute inflammatory demyelinating polyradiculoneuropathy. Muscle \& Nerve 1985;8:528-539.

2. Arnason BGW, Winkler GF, Hadler NM. Cell-Mediated Demyelination of Peripheral Nerve in Tissue Culture. Lab Invest 1969;21:110.

3. Arnason BGW. Acute inflammatory demyelinating polyneuropathies. In: Dyck PJ, Thomas PK, Lambert EH, Bunge R. ed. Peripheral neuropathy. Philladelphia. W.B. Saunders Co., 2nd ed. 1984:20502100.

4. Arsura EL, Bick A, Brunner NG, et al. High-dose intravenous immunoglobulin in the management of myasthenia gravis. Arch Intern Med 1986;146:1365-1368.

5. Asbury AK, Arnason BGW, Adams RD. The inflammatory lesion in idiopathic polyneuritis. Its role in pathogenesis. Medecine 1969;48:173-215.

6. Asbury AK, Arnason BWG, Karp HR, et al. Criteria for diagnosis of Guillain-Barré syndrome. Ann Neurol 1978;3:565-566.

7. Astrom KE, Waksman BH. The passive transfer of experimental allergic encephalomyelitis and neuritis with living lymphoid cells. J Path Bact 1962;83:89.

8. Bänffer JRJ, Duifhuis JCC, Mulder PGH. Counterimmunoelectrophoresis compared with complement fixation and passive haemagglutination tests in the evaluation of the immune response in Campylobacter infections. Antonie van Leeuwenhoek 1987;53:183-190.

9. Behar R, Penny R, Powell HC. Guillain-Barré syndrome associated with Hashimoto's thyroiditis. J Neurol 1986;233:233-236.

10. Behar R, Wiley C, McCutchan JA. Cytomegalovirus polyradiculopathy in aquired immune deficiency syndrome. Neurology 1987;37:557-561.

11. Blaser MJ, Reller LB. Campylobacter enteritis. N Engl J Med 1981; 305:444-1452.

12. Bordet JC, Follea G, Carosella E, et al. Intravenous high-dose IgG therapy induced alterations of spleen lymphycyte IgM secretion and $\mathrm{T}$ cell subsets in patients with idiopathic thrombocytopenic purpura. Thromb Res 1987;47:165-174.

13. Bradford JR, Bashford EF, Wilkson JA. Acute Infective Polyneuritis. Quart J Med 1918;12:88.

14. Brettle RP, Gross M, Legg NJ, et al. Treatment of acute polyneuropathy by plasma exchange. Lancet $1978 ; 2: 1100$.

15. Briscoe DM, McMenamin JB, O'Donohoe NV. Prognosis in GuillainBarré Syndrome. Arch Dis Child 1987;62:733-735.

16. Brostoff S, Sacks H, Canto M Dal. The P2 protein of bovine root myelin: isolation and some chemical and immunological properties. $\mathrm{J}$ of Neurochemistry 1974;23:1037-1043.

17. Brown WF, Feasby TE. Conduction block and denervation in 
Guillain-Barré polyneuropathy. Brain 1984;107:219-239.

18. Brown MJ, Rosen JL, Lisak RP. Demyelination in vivo by GuillainBarré syndrome and other human serum. Muscle \& Nerve 1987;10:263-271.

19. Burleson DG, Mason AD, McManus AT, et al. Lymphocyte phenotype and function changes in burn patients after intravenous IgG therapy. Arch Surg 1988;123:1379-1382.

20. Bussel JB, Lalezari P, Hilgartner MW, et al. Reversal of neutropenia with intravenous gammaglobulin in autoimmune neutropenia of infancy. Blood 1983;62:398-400.

21. Carreras LO, Perz GN, Xavier DL, et al. Autoimmune Factor VIII Inhibitor Responsive to Gammaglobulin without In Vitro Neutralisation. Thrombosis and Haemostasis 1988;60:343.

22. Casamajor L. Acute Ascending Paralysis Among Troops: pathologic Findings. Arch Neurol Psychiat 1919;2:605.

23. Clague JE, MacMillan RR. Backache and the Guillain-Barré syndrome: a diagnostic problem. B Med J 1986;293:325-326.

24. Cohen J. A coefficient of agreement for nominal scales. Education and Psychological Measurement 1960;20:37-46.

25. Cole GF, Matthew DJ. Prognosis in severe Guillain-Barré Syndrome. Arch Dis Child 1987;62:288-291.

26. Consensus Conference. The utility of therapeutic plasmapheresis for neurological disorders. JAMA 1986;256:1333-1337.

27. Constant OC, Bently CC, Denman AM, et al. The Guillain-Barré syndrome following Campylobacter enteritis with recovery after plasma exchange. J Infect 1983;6:89-91.

28. Cook JD, Tindall RAS, Walker J, et al. Plasma Exchange as a Treatment of Acute and Chronic Idiopathic Autoimmune Polyneuropathy: Limited Success. Neurology 1980;30:361-362.

29. Cook L, Howard JF, Folds JD. Immediate effects of intravenous IgG administration on peripheral blood $\mathrm{B}$ and $\mathrm{T}$ cells and polymorphonuclear cells in patients with myasthenia gravis. J Clin Immunol 1988;8:23-31.

30. Cook SD, Dowling PC, Murray MR, et al. Circulating Demyelinating factors in Acute Idiopathic Polyneuropathy. Arch Neurol 1971;24:136144.

31. Cornblath DR, Mellitis ED, Griffin JW, et al. Motor conduction studies in Guillain-Barré Syndrome: description and prognostic value. Ann Neurol 1988;23:354-359.

32. Cruz M, Ernerudh J, Olsson T, et al. Occurrence and isotype of antibodies against peripheral nerve myelin in serum from patients with peripheral neuropathy and healthy controls. J Neurol Neurosurg Psychiatry 1988;51:820-825.

33. De Bont B, Matthews N, Abbott K, et al. Guillain-Barré syndrome associated with Campylobacter enteritis in a child. J Pediatrics 1986;109:660-662.

34. De Jager EAJ. Het syndroom van Guillain-Barré. Een onderzoek naar restverschijnselen. Thesis. Groningen 1988.

35. Delfraissy JF, Tchernia G, Laurian Y, et al. Suppressor cell function after intravenous gammaglobulin treatment in adult chronic idio- 
pathic thrombocytopenic purpura. Br J Haematol 1985;60:315-322.

36. Devathasan G, Hueh YK, Chong PN. High-dose intravenous gammaglobulin for myathenia gravis. Lancet 1984;2:809-810.

37. Dowling PC, Cook SD. Role of infection in Guillain-Barré syndrome: Laboratory confirmation of herpesvirus in 41 cases. Ann Neurol 1981;9 (suppl):44-55.

38. Draganesco S, Claudian J. Sur un cas de radiculonevrite curable (syndrome de Guillain-Barré) apparue au cours d'une osteomyelite du bras. Rev Neurol 1927;2:517-521.

39. Dyck PJ, Daube J, O'Brien P, et al. Plasma exchange in Chronic Inflammatory Demyelinating Polyradiculoneuropathy. N Eng J Med 1986;314:461-465.

40. Eberle E, Brink J, Azen S, et al. Early predictors of incom plete recovery in children with Guillain-Barré polyneuritis. J Pediatrics 1975;86:356-359.

41. Eidelberg D, Sotrel A, Vogel H, et al. Progressive polyradiculopathy in acquired immune deficiency syndrome. Neurology 1986;36:912-916.

42. Faed JM, Day B, Pollock M, et al. High-dose intravenous immunoglobulin in chronic inflammatory demyelinating polyneuropathy. Neurology 1989;39:422-425.

43. Fagius J, Osterman PO, Siden A, et al. Guillain-Barré syndrome following zimeldine treatment. J Neurol Neurosurg and Psychiatry 1985;48:65-69.

44. Faraq SS, Gelles DB. Yersinia arthritis and Guillain-Barré syndrome. N Engl J Med 1982;307:755.

45. Fateh-Moghadam A, Wick M, Besinger U. et al. High-dose intravenouis gammaglobulin for myasthenia gravis. Lancet 1984;1:848-849.

46. Feasby TE, Hahn AF, Gilber JJ. Passive transfer studies in GuillainBarré polyneuropathy. Neurology 1982;32:1159-1167.

47. Feasby TE, Gilbert JJ, Brown WF, et al. An acute axonal form of Guillain-Barré polyneuropathy. Brain 1986;109:1115-1126.

48. Fehr J, Hofmann V, Kappeler U. Transient reversal of thrombocytopenia in idiopathic thrombocytopenic purpura by high-dose intravenous gamma globulin. N Engl J Med 1982;306:1254-1258.

49. Finne J, Leinonen M, Makela PH. Antigenic similarities between brain components and bacteria causing meningitis. Lancet $1983 \mathrm{ii} ; 355-$ 357.

50. French Cooperative Group on Plasma Exchange in Guillain-Barré Syndrome: Efficiency of Plasma Exchange in Guillain-Barré Syndrome: Role of Replacement Fluids. Ann Neurol 1987;22:753-761.

51. Furusho K, Kamiya $\mathrm{T}$, Nakano $\mathrm{H}$, et al. High-dose intravenous gammaglobulin for Kawasaki's disease. Lancet 1984;2:1055-1058.

52. Gaedicke G, Teller WM, Kohne E, et al. IgG therapy in systemic lupus erythematosus - two case reports. Blut 1984;48:387-390.

53. Gajdos P, Outin H, Elkharrat D, et al. High-dose intravenous gammaglobulin for myathenia gravis. Lancet 1984;1:406-407.

54. Genis D, Busquets C, Manubens E, et al. Epidural morphine analgesia in Guillain-Barré syndrome. J Neurol Neurosurg Psychiatry 1989;52:999-1001.

55. Gianella-Borradori A, Hirt A, Luthy A, et al. Haemophilia due to 
Factor VIII inhibitors in a patient suffering from an autoimmune disease: treatment with intravenous immunoglobulin. Blut 1984;48:403-407.

56. Goldschmidt B, Menonna J, Fortunato J, et al. Mycoplasma antibody in Guillain-Barré syndrome and other neurological disorders. Ann neurol 1980;7:108-112.

57. Greenwood RJ, Hughes RAC, Bowden AN, et al. Controlled trial of plasma exchange in acute inflammatory polyradiculoneuropathy. Lancet 1984 i: 877-879.

58. Gross MLP, Legg NJ, Lockwood MC, et al. The treatment of inflammatory polyneuropathy by plasma exchange. J Neurol Neurosurg Psychiatry 1982;45:675-679.

59. Guillain G, Barré JA, Strohl A. Sur un syndrome de radiculonevrite avec hyperalbuminose du liquide cephalo-rachidien sans reaction cellulaire. Bull Mem Soc Med Hop Paris 1916;40:1462-1470.

60. Guillain G, Barré JA. Quelques remarques sur notres "Syndrome de radiculo-nevrite avec hyperalbuminose de liquide cephalo-rachidien sans reaction cellulaire". Rev Neurol 1936;68:573-582.

61. Guillain-Barré Syndrome Study Group: Plasmapheresis and acute Guillain-Barré Syndrome. Neurology 1985;35:1096-1104.

62. Hahn AF, Gilbert JJ, Feasby TE. Passive transfer of demyelination by experimental allergic neuritis serum. Acta Neuropathologica (Berlin) 1980;49:169.

63. Halperin JJ, Little BW, Coyle PK, et al. Lyme disease: Cause of a treatable peripheral neuropathy. Neurology 1987;37:1700-1706.

64. Harrison BM, Hansen LA, Pollard JD, et al. Demyelination induced by serum from patients with Guillain-Barré syndrome. Ann Neurol 1984; 15:163-170.

65. Haymaker W, Kernohan JW. Landry-Guillain-Barré Syndrome Clinicopathological Report of Fifty Fatal Cases and Critique of Literature. Medecine 1949;28:59-149.

66. Hilgartner MW, Bussel J. Use of Intravenous Gamma Globulin for the Treatment of Autoimmune Neutropenia of Childhood and Autoimmune Hemolytic Anemia. American J Med 1987;83 (suppl 4a):2529.

67. Hogg RV, Craig AT. Central limit theorem.In: Introduction to mathemetical statistics. Mc Millan Company, Londen 1971.

68. Holmes G. Acute Febrile Neuritis. Brit Med J 1917;2:37.

69. Huestis DW. Mortality in therapeutic haemaphersis. Lancet $1983 ; 1: 1043$.

70. Hughes RCA, Newsom-Davis JM, Perkin GD, et al. Controlled trial of prednisolon in acute polyneuropathy. Lancet 1978; ii:750-753.

71. Hughes RAC, Gray IA, Kadlubowsky M. Immune response in experimental allergic neuritis. Neurology 1980;30:409.

72. Hughes RAC, Kadlubowsky M, Hufschmidt A. Treatment of Acute Inflammatory Polyneuropathy. Annals Neurol 1981:9(suppl);125-133.

73. Hughes RAC, Winer JB. Guillain-Barré syndrome. In: Matthews WB, Glaser GH.ed. Recent Advances In Clinical Neurology 4. Churchill Livingstone 1984:19-49.

74. Hughes RAC, Gray IA, Gregson NA, et al. Immune Responses to 
Myelin Antigens in Guillain-Barré Syndrome. J of Neuroimmunology 1984;6:303-312.

75. Ilyas AA, Willison HJ, Quarles RH. Serum antibodies to gangliosides in Guillain-Barré syndrome. Ann Neurol 1988;23;440-447.

76. Imbach $\mathrm{P}$, Barandum S, d'Apuzzo V, et al. High-dose intravenous gammaglobulin for idiopathic thrombocytopenic purpura in childhood. Lancet 1981;i:1128-31.

77. Ippoliti G, Cosi V, Piccolo G, et al. High-dose intravenous gammaglobulin for myasthenia gravis. Lancet 1984;2:809.

78. Iqbal A, Oger JJF, Arnason BGW. Cel Mediated Immunity in Idiopathic Polyneuritis 1981;9 (suppl):65-69.

79. Jahnke U, Fischer EH, Alvord EC. Sequence Homology Between Certain Viral Proteins and Proteins Related to Encephalomyelitis and Neuritis. Science 1985;229:282-284.

80. Kadlubowski M, Hughes RAC. Identification of the neuritogen responsible for EAN. Nature 1979;277:140-141.

81. Kadlubowski M, Gregson NA, Hughes RAC. Spontaneous and experimental neuritis and the distribution of the myelin protein P2 in the nervous system. J of Neurochemistry 1983;42:123-129.

82. Kaldor J, Speed BR. Guillain-Barré syndrome and Campylobacter jejuni: a serological study. Br Med J 1984;288:1867-1870.

83. Kaslow RA, Sullivan-Bolyai JZ, Hafkin B, et al. HLA antigens in Guillain-Barré syndrome. Neurology 1984;34:240-242.

84. Keenlyside RA, Schonberger LB, Bregman DJ, et al. Fatal GuillainBarré syndrome after the national influenza immunization program. Neurology 1980;30:929-933.

85. Kennedy F. Infective Neuronitis. Arch Neurol Psychiat 1919;2:621.

86. Kennedy RH, Danielson MA, Mulder DW, et al. Guillain-Barré syndrome: a 42-year epidemiological and clinical study. Mayo Clin Proc 1978;53:93-99.

87. Kinnunen E, Farkkiloa M, Hovi T, et al. Incidence of Guillain-Barré syndrome during a nationwide oral poliovirus vaccine campaign. Neurology 1989;39:1034-1036.

88. Kleyweg RP, Meche FGA van der, Meulstee J. Treatment of GuillainBarré Syndrome with high-dose gammaglobulin. Neurology 1988;38:1639-1641.

89. Kleyweg RP, van der Meche FGA, Loonen MCB, de Jonge J, Knip B. The natural history of Guillain-Barré syndrome in 18 children and 50 adults. J Neurol Neurosurg Psychiatry 1989;52:853-856.

90. Kleyweg RP, van der Meche FGA, Hetzberger LI, et al. The simultaneous occurrence of Guillain-Barré syndrome and acute Idiopathic Thrombocytopenic Purpura - a case report. submitted for publication.

91. Kohler A, de Torrente A, Inderwildi B. Fisher's Syndrome Associated with Campylobacter jejuni Infection. Eur.Neurol 1988;28:150-151.

92. Kohler PC. Guillain-Barré syndrome following Campylobacter jejuni enteritis. Arch Neur 1987;44:1219.

93. Koski CL. Guillain-Barré syndrome. In Johnson ed. Neurologic Clinics 2:2 Neurovirology. W.B.Saunders Company 1984.

94. Koski CL, Gratz E, Sutherland J, et al. Clinical correlation with antiperipheral-nerve myelin antibodies in Guillain-Barré Syndrome. Ann 
Neurol 1986;19:573-577.

95. Koski CL, Chou D, Jungalwala FB. Myelin Lipids Bound by Serum Antibodies to Peripheral Myelin ( a-PNM Ab) in Patients with Guillain-Barré Syndrome. Neurology 1987;37 (suppl) :253.

96. Kosunen TU, Kaurane O, Martio J, et al. Reactive arthritis after Campylobacter jejuni enteritis in patients with HLA-B27. Lancet 1980;1312-1313.

97. Kurland LT, Wiederholt WC, Kirkpatrick JW, et al. Influenza Vaccine and Guillain-Barré Syndrome: Epidemic or Artifact? Arch Neurol 1985;42:1089-1090.

98. Lambert EH, Mulder DW. Nerve conduction in Guillain-Barré Syndrome. Electroencephalography and Clinical Neurophysiology 1964;17:86.

99. Lampert PW. Mechanism of demyelination in experimental allergic neuritits. EM studies. Laboratory Investigation 1969;20:127-138.

100. Landis JR, Koch GG. A review of statistical methods in the analysis of data arising from observer reliability studies. Statistica Neerlandica 1975;29:151-161.

101. Landis RJ, Koch GG. The measurement of observer agreement for catagorial data. Biometrics 1977;33:159-174.

102. Latov N, Gross RB, Kastelman J, et al. Neurology 1981;31:1530-1534.

103. Lee ML, Kingdon HS, Hooper I, et al. Safety of an intravenous immunnoglobulin preparation: Lack of seroconversion for human immunodeficiency virus antibodies. Clin Therapeutics 1987;1:300-303.

104. Lee ML, Courter SG, Tait D, et al. Long-term evaluation of intravenous immune globulin preparation with regard to non-A, non-B hepatitis safety. In: A.J. Zuckerman (ed). Viral Hepatitis and Liver Disease. New York: Alan R. Liss, Inc, 596-599.

105. Leneman F. The Guillain-Barré Syndrome; Defenition, Etiology, and Review of 1100 Cases. Arch Intern Med 1966;118:139-144.

106. Löffel NB, Rossi LN, Mumenthaler M, et al. The Landry-GuillainBarré Syndrome. Complications, prognosis and natural history in 123 cases. J Neurol Sci 1977;33:71-79.

107. Lundkvist I, van Doorn PA, Vermeulen M, et al. Regulation of Autoantibodies in Inflammatory Demyelinating Polyneuropathy: Spontaneous and Therapeutic. Immunological Reviews 1989;110:105-117.

108. Makuch R, Simon R. Sample size requirements for evaluating a conservative therapy. Cancer Treat Rep 1978;62:1037-1040.

109. Mark B, Hurwitz BJ, Olanov CW, et al. Plasmapheresis in idiopathic inflammatory polyradiculopathy. Neurology 1980;30:361.

110. Marshall J. The Landry-Guillain-Barré syndrome. Brain 1963;86:5566.

111. Masucci EF, Kurtzke JF. Diagnostic criteria for the Guillain-Barré syndrome. An analysis of 50 cases. J Neurol Sci 1971;13:483-501.

112. McCombe PA, Pollard JD, Mc Leod JG. Chronic inflammatory demyelinating polyradiculoneuropathy: A clinical and electrophysiological study of 92 cases. Brain 1987;110:1617-1630.

113. McFarland HR, Heller GL, Arbor A. Guillain-Barré disease complex. A statement of diagnostic criteria and analysis of 100 cases. Arch Neurol 1966;14:196-201. 
114. McKahn GM, Griffin JW, Cornblath DR, et al. Plasmapheresis and Guillain-Barre Syndrome: Analysis of prognostic factors and the effect of plasmapheresis. Ann Neurol 1988;23:347-353.

115. McLeod JG, Walsh JC, Prineas JW, et al. Acute idiopathic polyneuritis: A Clinical and Electrophysiological Follow-up Study. J Neurol Sciences 1976;27:145-162.

116. McLeod JG. Electrophysiological studies in the Guillain-Barré Syndrome. Ann Neurol 1981;9(suppl):20-26.

117. McQuillen MP. Idiopathic polyneuritis: serial studies of nerve and immune functions. J Neurol Neurosurg Psychiatry 1971;34:607-615.

118. Medical Research Council. Aids to the investigation of the peripheral nervous system. London: Her Majesty's Stationary Office 1976.

119. Melnick SC. Thirty-eight cases of the Guillain-Barré syndrome: an immunological study. Brit Med J. 1963;1:368-373.

120. Melnick SC, Flewett TH. Role of infection in the Guillain-Barré syndrome. J Neurol Neurosurg Psychiat 1964;27:395-407.

121. Miller RG, Peterson GW, Daube JR, et al. Prognostic value of electrodiagnosis in Guillain-Barré Syndrome. Muscle \& Nerve 1988;11:769-774.

122. Molnar GK, Mertsola J, Erkko M. Guillain-Barré syndrome associated with Campylobacter infection. $\mathrm{Br}$ Med J 1982;285: 652.

123. Mosimann JM, Jung G, Schar V, et al. Serologische diagnose menslicher Campylobacter-infectionen. Schweiz. Med. Wochenschr. 1981;111:846-853.

124. Newburger JW, Takahashi M, Burns JC, et al. The treatment of Kawasaki syndrome with intravenous gamma globulin.

125. Newland AC, Treleaven JG, Minchinton RM, et al. High-dose intravenous IgG in adults with autoimmune thrombocytopenia. Lancet 1983;i:84-87.

126. Newland AC. Idiopathic thrombocytopenic purpira and IgG: A review. J Infection 1987;15(suppl):41-49.

127. Nyland H, Aarli JA. Guilain-Barré syndrome: demonstration of antibodies to peripheral nerve tissue. Acat Neurol Scand 1978;58:35-43.

128. Oomes PG, van der Meche FGA, Markus-Sillevis L, et al. In vivo effects of sera from Guillain-Barré subgroups: an electrophysiological and histological study on rat nerves. Submitted for publication.

129. Osler W. The Principles and Practice of Medicine. First edition. New York, Appleton, 1892.

130. Osterman PO, Fagius J, Safwenberg J, et al. Treatment of the Guillain-Barré Syndrome by Plasmapheresis. Arch Neurol 1982;39:148-154.

131. Osterman PO, Lundemo G, Pirskanen R, et al. Beneficial effects of plasma exchange in acute inflammatory polyradiculoneuropathy. Lancet 1984 ii; 1296-1299.

132. Osterman PO, Fagius J, Safwenberg J, et al. Early relapses after plasma exchange in acute inflammatory polyradiculoneuropathy. Lancet 1986:2;1161.

133. Osterman PO, Fagius J, Safenberg J, et al. Early relapse of acute inflammatory polyradiculoneuropathy after succesfull treatment with plasma exchange. Acta Neurol Scand 1988;77:273-277. 
134. Osterman PO, Vedeler CA, Ryberg B, et al. Serum antibodies to peripheral nerve tissue in acute Guillain-Barré syndrome in relation to outcome of plasma exchange. J Neurol 1988;235: 285-289.

135. Pleasure DE, Lovelace RE, Duvoisin RC. The prognosis of acute polyradiculoneuritis. Neurology 1968;18:1143-1148.

136. Pocock SJ: Clinical Trials. T. Wiley and Sons, 1985.

137. Pollack S, Cunningham-Rundles C, Smithwick EM, et al. High-dose intravenous gamma globulin for autoimmune neutropenia. N Engl J Med 1982;307:253.

138. Pryor WM. Guillain-Barré syndrome associated with Campylobacter infection. Aust NZ J Med 1984;14:687-688.

139. Rhodes KM, Tattersfield AE. Guillain-Barré syndrome associated with Campylobacter infection. Br Med J 1982;285:173-174.

140. Rodnitzky RL, Goeken JA. Complications of Plasma Exchange in Neurological Patients. Arch Neurol 1982;39:350-354.

141. Ropper AH, Shahani B, Huggins CE. Improvement in 4 Patients with Acute Guillain-Barré Syndrome After Plasma Exchange. Neurololy 1980;30:361.

142. Ropper AH, Shahani BT. Pain in Guillain-Barré syndrome. Arch Neurol 1984;41:511-514.

143. Ropper AH, Albers JW, Addison R. Limited relapse in GuillainBarré syndrome after plasma exchange. Arch Neurol 1988;45: 314315.

144. Ropper AH. Campylobacter Diarrhea and Guillain-Barré syndrome. Arch Neurol 1988;45:655-656.

145. Rossi LN, Mumenthaler M, Lutsch J, et al. Guillain-Barré Syndrome in children with special reference to the natural history of 38 personal cases. Neuropadiatrie 1976;7:42-51.

146. Rostami A, Brown MJ, Lisak RP, et al. The Role of Myelin P2 Protein in the Production of Experimental Allergic Neuritis. Ann Neurol 1984; 16:680-685.

147. Rotteveel JJ, Mullaart RA; Weemaes CMR, et al. Plasmaferese bij twee kinderen met het Guillain-Barré Syndroom. T. Kindergeneesk 1983;51:2:57-62.

148. Ruiz-Palacios GM, Torres J, Torres NI, et al. Cholera like enterotoxin produced by Campylobacter jejuni. Lancet i 1983;250-253.

149. Rumpl E, Mayr U, Gerstenbrand F, et al. Treatment of GuillainBarré Syndrome by Plasma Exchange. J Neurol 1981;225:207-217.

150. Ryberg B, Hindfelt B, Nilsson B, et al. Antineural antibodies in Guillain-Barré Syndrome and Lymphocytic Meningoradiculitis (Bannwarth's Syndrome). Arch Neurol 1984;41:1277-1281.

151. Saida T, Saida K, Silverberg D, et al. Experimental allergic neuritis induced by galactocerebroside. Ann Neurol 1981; 9 (suppl) :87-101.

152. Saida T, Saida K, Lisak RP, et al. In vivo demyelinating activity of sera from patients with Guillain-Barré syndrome. Ann Neurol 1982;11:69-75.

153. Salama A, Mueller-Eckhardt C, Kiefel V. Effect of intravenous immunoglobulin in immune thrombocytopenia. Lancet 1983;ii:193195.

154. Samantray SK, Johnson SC, Mathai KV, et al. Landry-Guillain-Barré 
syndrome: a study of 302 cases. Med J Aust 1977;2:84-91.

155. Samantray SK. Landry-Guillain-Barré syndrome in typhoid fever. Aust NZ J Med 1977;7:307-308.

156. Schonberger LB, Bregman DJ, Sulliban-Bolyai JZ, et al. GuillainBarré syndrome following vaccination in the National Influenza Immunization Program, United States, 1976-1977. Am J Epidemiol 1979;110:105-123.

157. Schwartz RS. Overwiew of the Biochemistry and Safety of a New Native Intravenous Gamma Globulin, IGIV, pH4.25 The American Journal of Medicine 1987;88 suppl 4A: 46-51.

158. Seifried E, Pindur G. Stotter H, et al. Treatment of refractory chronic idiopathic thrombocytopenic purpura with high dose intravenous immunoglobulin. Blut 1984;48:369-376.

159. Shumak KH, Rock GA. Therapeutic plasma exchange. N Engl J Med 1984;310:762-771.

160. Shy GM, McEachern D. Further studies on the effect of cortisone and ACTH in neurological disorders. Brain 1951;74:354-362.

161. Sliman NA. Outbreak of Guillain-Barré syndrome associated with water pollution. $\mathrm{Br}$ Med J 1978;1:751-752.

162. Sovilla JY, Regli F, Francioli PB. Guillain-Barré syndrome following Campylobacter jejuni enteritis. Arch Intern Med 1988;148:739-741.

163. Speed BR, Kaldor J, Cavanagh P. Guillain-Barré syndrome associated with Campylobacter jejuni enteritis. J Infection 1984;8:8586.

164. Speed BR, Kaldor J. Guillain-Barré syndrome associated with Campylobacter infection. Aust NZ J Med 1985;15:269.

165. Speed BR, Kaldor J, Watson J, et al. Campylobacter jejuni/Campylobacter coli - associated Guillain-Barré syndrome: Immunoblot confirmation of the serological response. Med J Aust 1987;147:13-16.

166. Sterman AB, Nelson S, Barclay P. Demyelinating neuropathy accompanying Lyme disease. Neurology 1982;32:1302-1305.

167. Stewart GJ, Pollard JD, McLeod JG, et al. HLA antigens in the Landry-Guillain-Barré syndrome and chronic relapsing polyneuritis. Ann Neurol 1978;4:285-289.

168. Sultan Y, Maisonneuve P, Kazatchkine MD, et al. Anti-idiotypic suppression of autoantibodies to factor VIII (Anti haemophilic Factor) by high-dose intravenous gammaglobulin. Lancet 1984;2:765768.

169. Sumner AJ. The physiological basis for symptoms in Guillain-Barré syndrome. Ann Neurol 1981;9 (suppl) :28-30.

170. Swick HM, McQuillen MP. The use of steroids in the treatment of idiopathic polyneuritis. Neurology 1976;26:205-212.

171. Tindall RSA. Humoral factors in inflammatory disorders of the centrral and peripheral nervous system. $J$ of Neuroimmunology 1988;20:283-296.

172. Toyka KV, Augspach R, Paulus W, et al. Plasma Exchange in Polyradiculoneuropathy. Ann Neurol 1980;8:205.

173. Toyka KV, Heininger K. Humoral factors in peripheral nerve disease. Muscle \& Nerve 1987;10:222-232. 
174. Tse KS, Arbesman CE, Tomasi TB, et al. Demonstration of antimyelin antibodies by immunofluorescence in Guillain-Barré syndrome. Clin Exp Immunol 1971;8:881-887.

175. Tsubakio T, Kurata Y, Katagiri S, et al. Alteration of $T$ cell subsets and immunoglobulin synthesis in vitro during high dose gammaglobulin therapy in patients with idiopathic thrombocytopenic purpura. Clin Exp Immunol 1983;53:697-702.

176. Uhr JW, Moller G. Regulatory effect of antibody on the immune response. Adv Immunol 1968;8:81-127.

177. Van der Meche FGA, Meulstee J. Guillain-Barré syndrome: a model of random conduction block. J Neurol Neurosurg Psychiatry 1988;51:1158-1163.

178. Van der Meche FGA, Meulstee J, Vermeulen M, et al. Patterns of conduction failure in the Guillain-Barré syndrome Brain 1988;111:405-416.

179. Van der Meche FGA, Vermeulen M, Busch HFM. Chronic inflammatory demyelinating polyneuropathy: conduction failure before and during immunoglobulin or plasma therapy. Brain 1989;112:1563-1571.

180. Van der Meche FGA, Meulstee J, Kleyweg RP. Axonal damage in Guillain-Barré syndrome - submitted for publication.

181. Van Doorn PA, Brandt A, Vermeulen M. Anti-neuroblastoma cell line antibodies in inflammatory demyelinating polyneuropathy: inhibition in vitro and in vivo by intravenous immunoglobulin. Neurology 1988;38:1592-1595.

182. van Heyningen WE. Gangliosides as membrane receptors for tetanus toxin,cholera toxin and serotonin. Nature 1974;249:415-417.

183. Vedeler CA, Nyland H, Matre R. Antibodies to Peripheral Nerve Tissue in Sera from Patients with Acute Guillain-Barré Syndrome Demonstrated by a mixed Haemagglutination Technique. J of Neuroimmunology 1982;2:209-214.

184. Vedeler CA, Matre R. Nyland H. Immunoglobulins in serum and cerebrospinal fluid from patients with acute Guillain-Barré syndrome. Acta Neurol Scand 1986;73:388-393.

185. Vermeulen M, van der Meche FGA, Speelman JD, et al. Plasma and Gamma Globulin infusion in chronic inflammatory polyneuropathy. J Neurosci 1985;70:317-326.

186. Vos JJE, van Aken WG, Engelfriet CP, et al. Intravenous gammaglobulin therapy in idiopathic thrombocytopenic purpura. Vox Sang 1985;49:92-100.

187. Waksman BH, Adams RD. Allergic neuritis: an experimental disease of rabbits induced by the injection of peripheral nervous tissue and adjuvants. J of Experimental Medicine 1955;203:213-235.

188. Westall FC, Root-Bernstein R. Cause and prevention of postinfectious and ii;251-252.

189. Wexler I. Sequence of demyelination - remyelination in GuillainBarré disease. J Neurol Neurosurg Psychiatry 1983;46:168-174.

190. Winer JB, Hughes RAC, Osmond C. A prospective study of acute idiopathic neuropathy. I. Clinical features and their prognostic value. J Neurol Neurosurg Psychiatry 1988;51: 605-612.

191. Winer JB, Hughes RAC, Anderson MJ, et al. A prospective study of 
acute idiopathic neuropathy II. Antecedent events. J Neurol Neurosurg Psychiatry 1988;51:613-618.

192. Wroe SJ, Blumhardt LD. Acute polyneuritis with cranial nerve involvement following Campylobacter jejuni infection. J Neurol Neurosurg Psychiatry 1985;48:593.

193. Zimmermann R, Kommerell B, Harenberg J, et al. Intravenous IgG for patients with spontaneous inhibitor to Factor VIII. Lancet 1985;1:273-274.

194. Zweiman B, Rostami A, Lisak RP, et al. Immune reactions to P2 protein in human inflammatory demyelinative neuropathies. Neurology 1983;33:234-237. 


\section{ACKNOWLEDGEMENTS}

This thesis could only be completed with the help and contribution of many.

Prof.Dr. A. Staal created an environment where optimal patient care could be combined with good research. He supported me with many stimulating remarks.

I am much indepted to Dr. F.G.A. van der Meché, the principle investigator of the Dutch Guillain-Barré trial. He made many valuable comments and supported me continuously during the study.

Prof. Dr. .F.M. Busch gave many helpful comments.

P.G. Oomes, Dr. Ir P.I.M. Schmitz and Drs. J. Meulstee deserve my gratitude for fruitful discussions on immunological, statistical, neurophysiological and non neurological subjects.

Mrs. R.M. van den Hoven gave excellent secretarial help.

Furthermore, I would like to thank all my colleagues at the neurology department for participating in the interobserver studies.

Dr. R.J. Bänffer, Mrs. J.C.C. Duifhuis and Dr. Ph.H. Rothbart performed many serological studies.

The enthousiastic help of drs. D.H.M. Zuidgeest, drs. H.M.A. van Gemert and drs. J.J. de Boer in randomizing and follow-up of some GBS patients is very much appreciated.

The Dutch Guillain-Barre trial is only possible with the help of many participating neurologists. I am much indepted to them, their names are in appendix 2.

Drs. P.A.Th. Carbaat and drs. L.I. Hertzberger, my present colleagues, provided me, without any hesistance, with the extra time that I needed to finish this thesis.

Finally, most of all, my wife Margreet, for her patience and stimulating remarks. 


\section{LIST OF PUBLICATIONS}

Kleyweg RP, van der Meché FGA.

Plasma-uitwisseling bij neurologische ziekten.

in Hemaferese; redactie Dr.J.Ph.H.B.Sybesma, Prof.dr.L.Kater

Rode Kruis Bloedbank " Zuid-West Nederland " ISBN 90-9002144-2;1987.

van der Meché FGA, Kleyweg RP, Meulstee J.

Guillain-Barré syndrome: Treatment with high-dose intravenous gammaglobulin. J of Neuroimmunology 1987;16/1;177.

van der Meché FGA, Kleyweg RP, Meulstee J.

Intravenous gammaglobulin (IVGG) versus plasmapheresis trial in patients with acute Guillain-Barré syndrome (GBS).

Clinical Neurology and Neurosurgery 1987;89-1:62-63.

van der Meché FGA, Meulstee J, Kleyweg RP.

Conduction block in acute inflammatory polyneuropathy.

Lancet 1985;ii:1302-1303.

Kleyweg RP, van der Meché FGA, Meulstee J.

Treatment of Guillain-Barré syndrome with high-dose gammaglobulin.

Neurology 1988;38:1639-1641.

Kleyweg RP, van der Meché FGA, Loonen MCB, de Jonge J, Knip B. Comparison of the natural history of Guillain-Barré syndrome in 18 children and 50 adults. J Neurol Neurosurg Psychiatry 1989;52:

853-856.

Kleyweg RP, van der Meché FGA, Schmitz PIM.

Interobserver agreement in the assessment of muscle strength and functional abilities in Guillain-Barré syndrome. submitted for publication.

Kleyweg RP, van der Meché FGA.

Treatment related fluctuations in patients with Guillain-Barré syndrome after treatment with immunoglobulins or plasma exchange. submitted for publication. 
Kleyweg RP, van der Meché FGA.

Treatment of Guillain-Barré syndrome.

in: Neurologische Probleme des Intensivpatienten ; E.Deutsch et al eds. Springer-Verlag, Wien-New York 1990

Oomes PG, van der Meché FGA, Markus-Sillevis L, Meulstee J, Kleyweg RP.

In vivo effects of sera from Guillain-Barré subgroups: an electrophysiological and histological study on rat nerves. submitted for publication.

Van der Meché FGA, Meulstee J, Kleyweg RP.

Axonal damage in Guillain-Barré syndrome. submitted for publication.

Kleyweg RP, van der Meché, Hertzberger LI, Halkema DR.

The simultaneous occurrence of Guillain-Barré syndrome and acute Idiopathic Thrombocytopenic Purpura - a case report. submitted for publication.

Kleyweg RP, van der Meché, Bänffer JRJ, Schmitz PIM, Meulstee J, Rothbart PhP, Oomes PG.

Campylobacter jejuni/coli infection and Guillain-Barré syndrome. in preparation. 


\section{APPENDIX 1}

Criteria for diagnosis of Guillain-Barré syndrome summarised from the criteria for GuillainBarré syndrome established by the ad hoc NINCDS committee [6].

- Features required for the diagnosis

Progressive motor weakness of more than one limb

Areflexia or marked hyporeflexia

- Features strongly supportive of the diagnosis

A. Clinical features

Progression over days to a few weeks

Relative symmetry

Mild sensory symptoms or signs

Cranial nerve involvement

Recovery, starting usually $2-4$ weeks after progression stops

Autonomic dysfunction

Initial absence of fever

B. Cerebrospinal fluid features

Elevated CSF protein after 1 week of symptoms

Cell counts of no more than 10 mononuclear leukocytes $/ \mathrm{mm}^{3}$

C. Electrodiagnostic features

Nerve conduction slowing or prolonged $F$ waves

- Features that rule out the diagnosis

A current history of hexocarbon abuse

Abnormal porphyrin metabolism indicating acute intermittent porphyria

Recent diphtheritic infections

Evidence of lead intoxication with features consistent with lead polyneuropathy

A purely sensory syndrome

Evidence of poliomyelitis, botulism, toxic neuropathy, tick paralysis 


\section{APPENDIX 2}

Organization of the Dutch Guillain-Barré trial

Co-ordinating centre: University Hospital Dijkzigt, Erasmus University, Rotterdam.

General co-ordinator:F.G.A. van der Meché, neurologist

Clinical co-ordinator: R.P. Kleyweg, neurologist

Neurophysiological co-ordinator: J. Meulstee, neurologist

Organization trial office: R.M. van den Hoven.

Monitoring committee:

F.G.A. van der Meché, neurologist, chairman.

Members: H.F.M. Busch, neurologist, R.P. Kleyweg, neurologist, M.L. Lee, statistician, J.

Meulstee, neurologist, P.I.M. Schmitz, statistician.

\section{Centres:}

Academisch Ziekenhuis Rottcrdam: R.P. Kleyweg, J. Meulstee.

Academisch Ziekenhuis Groningen: A.E.J. de Jager, T.W. van Weerden.

Academisch Ziekenhuis Utrecht: P.L. Oey, J.P. Ter Bruggen,.

Academisch Medisch Centrum, Amsterdam: B.W. Ongerboer-Visser, J. Stam.

De Wever Ziekenhuis, Heerlen: C.L. Franke, J.W. Vredeveld.

Westeinde Ziekenhuis, Den Haag: W.F.M. Arts, A.W. de Weerd.

Academisch Ziekenhuis bij de Vrije Universiteit, Amsterdam: J.J. Heimans, C. Polman, R.P.M. Strijers.

St. Josephziekenhuis, Eindhoven: B.J. van Kasteren.

Ver. Ziekenhuizen Ziekenzorg, Enschede: E.M. de Vries-Leenders.

St. Elisabeth Ziekenhuis, Tilburg: A.A.W. Op de Coul, R.L.A.A. Schellens

Canisius-Wilhelmina Ziekenhuis, Nijmegen: C.W.G.M. Frenken, W.I.M. Verhagen.

St. Clara Ziekenhuis, Rotterdam: H.J. v.d. Brand, H.A.W. Sinnige.

St. Ziekenhuis Westelijke Mijnstreek, Sittard: J.J. Korten

Ziekenhuis Leijenburg, Den Haag: L.G.F. Sinnige, D.L.J. Tavy, A.K. Wattendorf.

Medisch Centrum Alkmaar: J.A. van Leusden.

Academisch Ziekenhuis Maastricht: C.J. Howeler, F. Spaans.

St. Ziekenhuis de Malberg, Arnhem: L. van der Graaff, G. Schouwink.

St. Maartens Gasthuis, Venlo: T.G. Segeren.

Ziekenhuis "De Lichtenberg", Amersfoort: J.L. v.d. Zwan.

Funding of the study:

The study was cofunded by Baxter Healthcare Corporation, Hyland Division and the American Red Cross. The study co-ordinators, monitoring committee and the centre investigators are, however, fully responsible for the design, conduct and publication of the results of the study. 


\section{CURRICULUM VITAE}

De schrijver van dit proefschrift werd op 4 juli 1955 te Rotterdam geboren. Hij bezocht de Rijks Scholengemeenschap te Oud-Beijerland waar in 1974 het diploma Atheneum B werd behaald. Vervolgens studeerde hij geneeskunde aan de Erasmus Universiteit te Rotterdam. Tijdens zijn studie vervulde hij 2 maanden een assistentschap op de afdeling neurologie en hij werd in 1981 tot arts bevorderd. Gedurende de militaire dienst was hij werkzaam op de afdeling neurologie van het Militair Hospitaal Dr. A. Matthysen te Utrecht. Vanaf 1 januari 1983 volgde de opleiding tot neuroloog in het Academisch Ziekenhuis Dijkzigt te Rotterdam (opleider: Prof. Dr. A. Staal). De opleiding klinische neurophysiologie werd gevolgd bij Dr. K. Mechelse. Op 1 januari 1988 werd hij ingeschreven in het specialisten register.

Sedert 1 januari 1990 is hij als staflid verbonden aan het Merwede ziekenhuis te Dordrecht. 
